Portland State University

PDXScholar

Summer 8-16-2016

\title{
Use of Distance Weighted Metrics to Investigate Landscape-Stream Temperature Relationships Across Different Temporal Scales
}

Eric Craig Watson

Portland State University

Follow this and additional works at: https://pdxscholar.library.pdx.edu/open_access_etds

Part of the Geography Commons, and the Water Resource Management Commons Let us know how access to this document benefits you.

Recommended Citation

Watson, Eric Craig, "Use of Distance Weighted Metrics to Investigate Landscape-Stream Temperature Relationships Across Different Temporal Scales" (2016). Dissertations and Theses. Paper 3117. https://doi.org/10.15760/etd.3113

This Thesis is brought to you for free and open access. It has been accepted for inclusion in Dissertations and Theses by an authorized administrator of PDXScholar. Please contact us if we can make this document more accessible: pdxscholar@pdx.edu. 


\title{
Use of Distance Weighted Metrics \\ to Investigate Landscape-Stream Temperature Relationships \\ Across Different Temporal Scales
}

\author{
by \\ Eric Craig Watson
}
A thesis submitted in partial fulfillment of the requirements for the degree of
Master of Science
in Geography

Thesis Committee:

Heejun Chang, Chair

Geoffrey Duh

Eugene Foster

Portland State University

2016 


\begin{abstract}
Stream ecosystems have experienced significant negative impacts from land use, resource exploitation, and urban development. Statistical models allow researchers to explore the relationships between these landscape variables and stream conditions. Weighting the relevant landscape variables based on hydrologically defined distances offers a potential method of increasing the predictive capacity of statistical models. Using observations from three grouped watersheds in the Portland Metro Area $(n=66)$, I have explored the use of three different weighting schemes against the standard method of taking an areal average. These four different model groups were applied to four stream temperature metrics: mean seven-day moving average maximum daily temperature (Mean7dTmax), number of days exceeding $17.8{ }^{\circ} \mathrm{C}(\operatorname{Tmax} 7 \mathrm{~d}>17.8)$, mean daily range in stream temperature (Range_DTR), and the coefficient of variation in maximum daily temperature (CV_Tmax). These metrics were quantified for the 2011 dry season. The strength of these model groups were also examined at a monthly basis for each of the four months within the dry season. The results demonstrate mixed effectiveness of the weighting schemes, dependent on both the stream temperature metric being predicted as well as the time scale under investigation. Models for Mean7dTmax showed no benefit from the inclusion of distance weighted metrics, while models for Range_DTR consistently improved using distance weighted explanatory variables. Trends in the models for 7dTmax $>17.8$ and $\mathrm{CV}_{-}$Tmax varied based on temporal scale. Additionally, all model groups demonstrated greater explanatory power in early summer months than in late summer months.
\end{abstract}




\section{Acknowledgements}

I would like to thank my adviser, Dr. Heejun Chang, for providing supportive feedback and invaluable suggestions, Dr. Geoffrey Duh for providing key technical feedback during the conceptual stages of this research project, and Dr. Gene Foster, whose water quality management class initiated my interest in the ecological importance of stream temperature. I am also deeply indebted to Zbigniew Grabowski, who contributed collaborative insight during the original development of the Python script that made this research possible. Additionally, many thanks to my friends and family for offering much appreciated support throughout the entire process. 


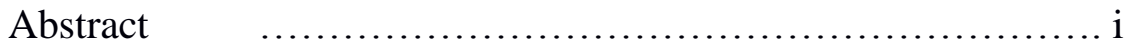

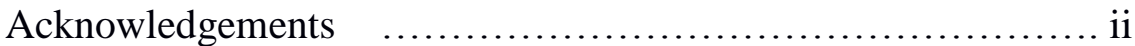

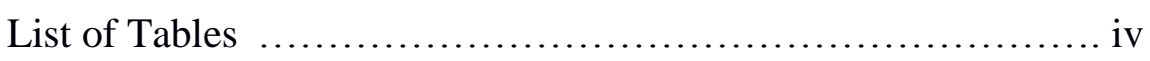

List of Figures $\quad$....................................

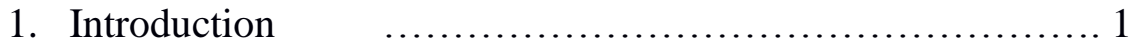

Stream Temperature Dynamics $\quad$.................. 1

Salmonids and Stream Temperature $\ldots . \ldots \ldots \ldots \ldots \ldots \ldots . \ldots$

Stream Temperature and Regulatory Standards ........... 4

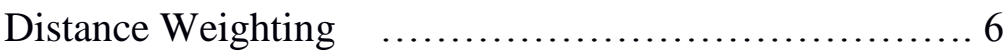

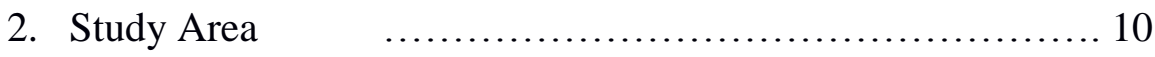

3. Data and Methods ..................................... 12

Distance Weighting Tool $\quad \ldots \ldots \ldots \ldots \ldots \ldots \ldots \ldots . \ldots . \ldots . \ldots 14$

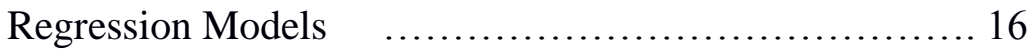

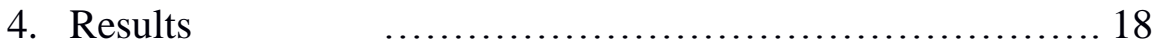

Mean 7-Day Average Maximum Temperature ............. 18

Average Daily Temperature Range $\quad \ldots . . . \ldots \ldots . . . . . . .19$

Coefficient of Variation in Maximum Temperature ...... 20

Number of Days Exceeding $17.8^{\circ} \mathrm{C} \quad \ldots \ldots \ldots \ldots \ldots . \ldots . \ldots 20$

5. Discussion ........................................ 22

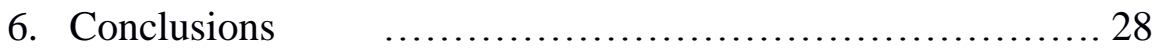

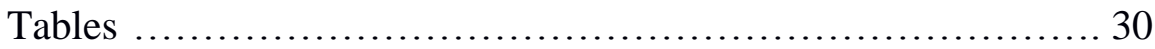

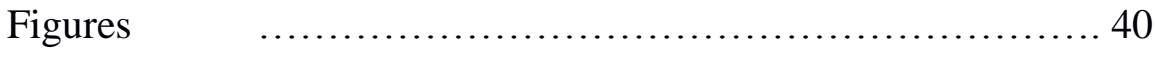

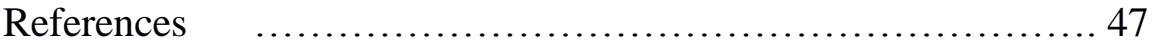

Appendix A: Spatial Variation in Model Results $\quad$............. 57

Appendix B: Python Script for the Distance Weighting Tool ..... 62 


\section{List of Tables}

Table 1: Landscape and climate characteristics 30

Table 2: Datasets used to build the regression models 31

Table 3: Evaluation metrics for 7-day average maximum temperature models ... 33

Table 4: Evaulation metrics for mean daily temperature range models _.... 34

Table 5: Evaluation metrics for coefficient of variation in temperature models .. 35

Table 6: Evaluation metrics for days exceeding $17.8^{\circ} \mathrm{C}$ models $\quad$............. 36

Table 7: Coefficient values from regression models for whole summer values .. 37

Table 8: Moran's I values for model residuals 39 


\section{List of Figures}

Figure 1: Conceptual diagram of stream temperature processes

Figure 2: Locations of stream temperature observation sites $\ldots \ldots \ldots \ldots \ldots \ldots \ldots 41$

Figure 3: Climograph of monthly average temperature and precipitation $\ldots 42$

Figure 4: Temperature variation across grouped watershed regions $\ldots \ldots \ldots \ldots 43$

Figure 5: Spatial variation of stream temperature metrics $\quad \ldots \ldots \ldots \ldots \ldots \ldots . \ldots 4$

Figure 6: Conceptual diagram of landscape averaging methods $\quad \ldots \ldots \ldots \ldots 45$

Figure 7: Correlation matrix of whole summer temperature variables ........ 46 


\section{Introduction}

The ecological ramifications of human interactions with the natural environment have are particularly evident when examining stream water quality (Allan 2004; Buck, Niyogi \& Townsend 2004; Herlihy, Stoddard \& Johnson 1998). Because streams are the coalescence of water running through the landscape, the quality of stream water often reflects the state of its surrounding landscape. Although stream ecosystems are affected by a variety of factors, stream temperature is highly influential as it both directly dictates habitability as well as also controlling other ecologically important parameters, such as dissolved oxygen (Cox 2003; Verberk, Durance, Vaughan \& Ormerod 2016).

\subsection{Stream Temperature Dynamics}

Stream temperature is a key physical and biological component of the stream lotic habitat system. Taken by itself, stream temperature can have significant impacts on the health of a stream (Johnson 2004; Poole \& Berman 2001; Sponseller, Benfield \& Valett 2001). Many aquatic organisms are poikilothermic and lack an efficient way of regulating their own body temperature. Therefore, stream temperature can be a determining factor in whether or not a stream reach is habitable.

Additionally, stream temperature is a determining factor for some important water chemistry variables such as dissolved oxygen and acidity. Indeed, stream temperatures can influence many of the chemical and metabolic processes that occur within the stream system (Caissie 2006). Thus, it is key to have the ability to accurately model and explain the spatial variation of stream temperature across an ecosystem. 
Through the perspective of heat dynamics, the determining factors for stream temperature are identified as the processes that exchanges heat energy with the stream (Boyd \& Sturdevant 1997). In general, the most significant physical processes that exchange heat energy with a waterbody, thereby altering its temperature, are insolation, longwave radiation, evaporation, convection, stream bed conduction, and groundwater exchange (Boyd \& Sturdevant 1997). The shade provided by a riparian canopy can block incoming solar radiation, reducing the amount of heat energy entering the stream water (Nash et al. 2009). Thus, any model constructed to explain the variation in stream temperatures should include information for as many of these processes as possible. The absence of any one of these variables has the potential to reduce the explanatory power of the resulting model.

In addition to the above mentioned processes, there are a large number of other variables that can influence stream temperature in urban streams to varying degrees. These could include more localized phenomena, such as the presence of a waste water treatment facility, or watershed-scale variables that can impact stream temperature in more indirect ways. Curve numbers and impervious surface are two examples of the latter, which are often included in statistical models for stream temperature (Arnold \& Gibbons 1996; Nelson \& Palmer 2007; Somers et al. 2013). Higher impervious surfaces will increase direct contact with sun as well as absorbing more solar radiation due to low albedo typically associated with dark surfaces. However, the effect of urban infrastructure on stream temperature is less clear. While some studies reported that road density was positively associated with stream temperature, other studies found no 
statistically significant relationship between mean stream temperature and road density in a tropical urban watershed (Ramirez et al. 2014.)

Both curve numbers and impervious surface area can be important factors for stream temperature for a number of reasons. Curve numbers are theoretical values representing the relative amount of runoff generated from a precipitation event, based on both land cover and underlying soil types (U.S. Department of Agriculture 1985). Differences in rainfall-runoff relationships can effect overland flow and flashiness, both of which can be associated with spatial variation in stream temperature (Somers et al. 2013). Meanwhile, impervious surface directly affects infiltration and baseflow, which can be a significant determinant for stream temperature (Nelson \& Palmer 2007; Figure $1)$.

\subsection{Salmonids and Stream Temperature}

Stream temperature generally displays cyclical trends across two temporal scales: daily cycles and seasonal cycles. In Oregon, the hottest months are generally July and August, while the coolest months are usually December and January (Oregon Department of Environmental Quality 2001). This variability presents challenges to aquatic organisms and especially to species that rely on stream temperature for the timing of largescale migrations or semelparous reproduction events, such as salmon (Battin et al. 2007; Holtby, McMahon \& Scrivener 1989). These organisms are affected by both seasonal and daily stream temperature variations, which play an integral role in both their metabolic activity and their mortality (Richter \& Kolmes 2005; Sawyer et al. 2004). 
In addition to their ecological importance, salmon have played an integral role in the cultural and economic history of the Pacific Northwest. For instance, in the late 1800s salmon canning operations dominated the Lower Columbia riverscape. Other notable historic pressures included large scale logging operations and the conversion of wetlands. So it is unsurprising that this economic history includes a degree exploitation that has led to the collapse of many salmon runs (Lichatowitz 1999).

This sequence of events is illustrated in the history of the Portland Metropolitan Area. For example, the Tualatin River once provided habitat and breeding areas for both Coho and Steelhead salmon. Decades of logging, manufacturing effluent release, and land cover conversion, particularly the destruction of riparian vegetation, has resulted in a loss in viable salmon habitat. Local agencies have attempted to solve the disappearance of salmon through the introduction of artificially bred salmon from local hatcheries. For instance, in conjunction with the construction of Hagg Lake dam, over 60,000 Coho and 10,000 Steelhead salmon were planted in the Upper Tualatin River basin (Lichatowitz 1999). Unfortunately, as is the general trend, the mere introduction of salmon into previously inhabited stream reaches will not prove successful without the analysis and restoration of suitable ecological conditions where these species can flourish.

\subsection{Stream Temperature and Regulatory Standards}

Since the implementation of the Clean Water Act (CWA) of 1972, the majority of stream water quality regulation has focused on point source pollution. Although programs that regulate point sources have become well established, many stream reaches are still 
not meeting water quality standards. This discrepancy has shifted the discussion towards ambient pollution, implementation of section 303d of the CWA, and the use of Total Maximum Daily Loads (TMDLs), which quantifies the target pollutant threshold that a waterbody can receive while still meeting water quality standards.

The specific pollutant loads deemed acceptable are determined through analysis of beneficial uses, such as drinking water, contact recreation, or industrial water supply. These beneficial uses can and do include some of the biological requirements of freshwater fish. Particularly in the Northwest, the requirements of salmon are often used to determine pollutant criteria. As illustrated above, stream temperature plays a critical role across many of the life stages of salmon, as they migrate, spawn, and smolt (Richter \& Kolmes 2005). Most of the temperature criteria for streams across the PortlandVancouver Metro Area were formulated to protect salmon.

A key tool used for the creation of TMDLs is water quality modeling. Models can generally be categorized as either statistical or deterministic. While deterministic, or process-based, modeling can lead to estimating the actual quantities of pollutant loading from individual sources, they also require vast amounts of data. Statistical models, on the other hand, require much less data and can help identify the relative association between explanatory variables and the water quality parameter under investigation. Due to the current emphasis on ambient pollution, it would be beneficial to investigate methods that could improve the way that explanatory variables are included in statistical models. The present study explores if, and to what degree, the application of distance based weights 
can improve the performance of landscape variables for explaining variations in stream temperature.

\subsection{Distance Weighting}

Parametric distance weighting is the method of weighting the value of a geographic variable based on their respective distance to a feature of interest (Van Sickle \& Johnson 2008). For water quality studies, weights can be calculated according to distance from a hydrologic feature, such a point in the stream or the stream bank. These weighting schemes operate on the lateral dimension of a stream system, which implicates factors acting across the landscape as they interact with the stream. In the field, the lateral dimension translates to the upstream landscape and the space through which soil moisture transport, overland flow, infiltration, and baseflow all occur. These processes take place over varying timescales and affect the stream to differing degrees, but all of them are mechanisms through which the landscape influences stream water quality (Walsh et al. 2005; Yates \& Bailey 2006).

The most common methods of incorporating the lateral dimension within stream water quality studies are through clipping landscape metrics down to a riparian buffer region or through parametric distance weighting (Gove, Edwards, \& Conquest 2001; Pratt \& Chang 2012; Schuft et al. 1999; Silva \& Williams 2001). Pruning down landscape information into buffer regions has been shown to be an effective way of filtering out only the land cover data that has the greatest effect on water quality in general and stream temperature in particular (Hunsaker \& Levine 1995; Hurley \& 
Mazumder 2013; Johnson et al. 1997; Sawyer et al. 2004; Sliva and Williams 2001). Several studies have demonstrated that metrics calculated from riparian buffer areas outperform whole-basin metrics when explaining water quality values (Chang 2008; Hurley \& Mazumder 2013; Johnson et al. 1997; Sawyer et al. 2004). These studies have been conducted in various environmental contexts, using tropical, arid, and temperate study areas, illustrating that distance-to-stream may be a universal determinant when investigating the significance of land cover - stream temperature relationships.

While the riparian buffer method may often increase the explanatory value of a landscape metric (Chang \& Psaris 2013), it does have some drawbacks. First, it is often unclear how to meaningfully assign a buffer distance. Previous studies have used a widely varying range of distances to define the riparian area, ranging from 30 meter to 5000 meters (Chang \& Psaris 2013; Nash et al. 2009; Sponseller, Benfield \& Valett 2001; Zhou, Wu \& Peng 2012). Theoretically, the buffer distance is meant to represent the riparian region around a stream, which by definition should represent the interface between land and the stream, and is seen as tightly bound to the stream itself, through both hydrological and ecological importance. In practice, this distance can be difficult to accurately determine, particularly if researches are working predominately through remotely sensed datasets. Furthermore, the distance may vary across different reaches of the same stream due to the potential differences in land-water interactions.

These drawbacks have led some researchers to opt for the alternative, parametric distance weighting (Van Sickle \& Johnson 2008). This method uses a mathematical function to assign weights as a continuous surface to land cover values. Commonly used 
functions include inverse distance weighting and exponential distance weighting, assigning higher weights closer to monitoring stations. Within the context of stream research, distance can be defined in a variety of ways and the way in which distances are defined will affect the resulting metric values. For example, distances can be defined in Euclidean space or in hydrologic space, i.e. the distances water would hypothetically travel throughout a landscape.

Euclidean distances are often vastly simpler to calculate, therefore many studies that have sought to include parametric distance weighting have defined distance in this manner (Gove, Edwards, \& Conquest 2001; Peterson 2011; Van Sickle \& Johnson 2008; Wente 2000). In comparison, hydrological distances can represent more hydrologically and ecologically relevant information. For example, two points in space may be relatively close to one another, but may be separated by a hydrologic barrier. Conversely, manmade infrastructure (ex. irrigation ditches and stormwater pipe networks) can significantly shorten the hydrological distances between a stream and its upland contributing area.

In addition to flow lengths, hydrological distances can also be defined more abstractly through concepts like hydrologic activity. Ver Hoef et al. (2014) have used this technique to some success, defining hydrologic activity as the relative amount of runoff passing through a point in the landscape as it travels to the observation location. Specifically, they have used this technique as a foundation for their Spatial Statistical Modeling (SSN) software package. Unlike that project, the present study aims to create a 
standalone tool for a number of different distance weighted metrics, which is not inherently tied to water quality modeling, but could be used in a variety of contexts.

The distance weighted metrics devised in this study are structured to incorporate flow distances, rather than Euclidean distance, with the aim that these weights will better reflect significance to the stream system. This study also investigates if there is a difference in how the weighted metrics perform when stream temperature is quantified at two different timescales and across the dry-season. The main goal of this study is the construction of distance-weighted metrics for landscape variables. The utility of this tool is then evaluated across two contexts. Firstly, does the use of distance-weighted metrics improve the explanatory power of statistical models for stream temperature? Secondly, how does the performance of these metrics, as well as the models' explanatory power, vary across dry season months (i.e. June through September)? 


\section{Study Area}

This study is composed of three watershed regions in the Portland-Vancouver Metropolitan Area (PMA): the Tualatin River Basin (TRB), Oregon, Johnson Creek, Oregon, and a number of subbasins in Clark County, Washington (Figure 2). Due to their geographic proximity, these areas all experience a very similar climate. In terms of precipitation, this area experiences fairly distinct wet and dry seasons. Over $50 \%$ of the annual precipitation occurs between the months of December and February (Lee \& Snyder 2009). In contrast, very little rainfall occurs between the months of June and September (Figure 3). Additionally, these summer months also experience the highest annual temperatures, including the occurrence of heatwaves. Because they are located in low elevations, none of these watersheds experience snowfall or snow accumulation in any significant magnitude. Despite their climatic similarity, each watershed in the three grouped watersheds differs in terms of elevation and land use, providing a diverse sample (Table 1).

At $1,340 \mathrm{~km}^{2}$, the largest watershed in this study is the Tualatin River Basin (TRB). It contains a gradient in land use from forested lands in its Coast Range headwaters, to agricultural lands in the rolling foothills, and urbanized land in the lower third of the watershed (Hoyer \& Chang 2014). Indeed, out of the three watersheds studied, land use is most diverse within the TRB. The upper watershed includes significant foresting activity, within state and national forests. Agricultural activity within the watershed's midlands includes both cultivated crops as well as pastures and orchards. The lower reaches of the Tualatin mainstem are notably slow moving and have at times 
even displayed degrees of thermal stratification (Oregon Department of Environmental Quality 2001).

Johnson Creek runs through Gresham and the Eastside of Portland. It has the highest percentage of urbanized land. Very little of the land cover in the Johnson Creek basin is forested, leaving almost $80 \%$ of it urban or agricultural (Lee \& Snyder 2009). This has had dramatic effects on the streamflow patterns of Johnson Creek, which displays flashiness and regularly experiences floods (Ahilan et al. 2016). But this has also led to a significant number of restoration projects within Johnson Creek, to address both flood management and water quality issues (Chang et al. 2014).

The observation locations available in Clark County, Washington are in a number of relatively small and distinct subbasins in and around the Salmon Creek watershed. In contrast to Johnson in particular, this watershed region is quite rural. Additionally, its proximity to the confluence of the Willamette and Columbia rivers means that this region also contains a number of wetlands and shallow lakes (Stohr, Cummings \& McKee 2011). A comparison of 7-day average maximum daily stream temperature data illustrate that this region also experiences lower stream temperatures, in general, than the locations in either the TRB or Johnson Creek (Figure 4). 


\section{Data and Methods}

The creation of distance weighted landscape metrics and the subsequent regression models required data for stream temperature, air temperature, land covers, hydrologic soil types, elevation, and stream locations (Table 2). Stream temperature, specifically, was chosen due a wealth of continuous data during the time period of interest. Stream temperature observation locations were chosen if they had hourly data for the summer of 2011, coinciding with the most recent year for which land cover data is available from the US Geological Survey. Summer was defined as the months June through September (122 days) and locations were included if they had hourly data for at least 115 days out of this period. Sixty-six sites met this criteria and were included in the study. For each location, four stream temperature variables were calculated: the mean 7day average daily maximum temperature (Mean7dTmax), the coefficient of variation for

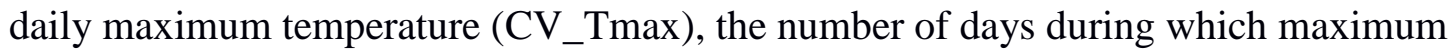
daily temperature exceeded $17.8^{\circ} \mathrm{C}(\operatorname{Tmax} 7 \mathrm{~d}>17.8)$, and the mean range between daily maximum and daily minimum temperatures (Mean_DTR).

These metrics were selected due to their ecological and regulatory significance. Mean7dTmax is a general measure that captures the average state of stream temperature. Given that precipitation and soil moisture content change over summer, landscape control for transporting water is likely to shift, which in turn affect streamflow amount in streams. Tmax $7 \mathrm{~d}>17.8$ is one of the most common regulatory measures used by ODEQ to evaluate temperature conditions in a stream. This threshold is established in stream temperature regulatory framework and is associated with rearing and migration of salmon 
species (Oregon Department of Environmental Quality 2001). CV_Tmax and Mean_DTR both quantify how temperature is varying across time. CV_Tmax measures temperature variation across the season or month, while Mean_DTR captures this variation across an average day (Figure 5). Studies have demonstrated that salmon are sensitive to temperature variation across time. In fact, even if temperatures remain below the threshold temperature $\left(17.8^{\circ} \mathrm{C}\right)$, dramatic fluctuations over short periods of time can be lethal (Hynes 1970; Richter \& Kolmes 2005).

These metrics were calculated on two different time scales. This was done to evaluate the relative sensitivity of stream temperature to landscape variables based on temporal scale. First, the metrics were calculated for the entire summer period, and then they were also calculated at the monthly-scale for each of the four summer months (June, July, August, and September).

Stream polylines and major watershed boundaries were procured from the National Hydrography Dataset (U.S. Environmental Protection Agency 2015). Large watershed boundaries were utilized to clip landscape datasets to clip the spatial extent of the area of interest and streamlines were necessary to confirm observation locations and refine the subbasin delineations that were subsequently determined using the distanceweighting tool.

Gridded air temperature information for the study area was downloaded from the University of Idaho's METDATA database (Abatzoglou 2011). This database provides historical climate information on a daily scale from 1979 to the present. Climate values for gridded points across the United States at a 4 kilometer resolution, which they 
generated from statistically downscaled NLDAS-2 data. Both daily minimum and maximum air temperature datasets were obtained through this catalog. Air temperature was included because previous research has demonstrated that air and stream temperatures are often correlated (Booth, Kraseski \& Jackson 2013; Chang \& Psaris 2013; Nelson \& Palmer 2007; Poole \& Berman 2001). The METDATA point nearest each stream temperature observation point was chosen and the dataset used to calculate mean 7-day moving average maximum daily air temperature (amax7) and average minimum daily air temperature (amin).

The 2011 land cover dataset from the National Land Cover Database was used to calculate percent riparian forest (perc_for). The riparian area was defined as extending 1 $\mathrm{km}$ upstream from the observation point and 50 meters on either side of the stream polyline. These dimensions were based on those successfully utilized previously in this study area (Chang \& Psaris 2013). The land cover dataset was also used in conjunction with soil information from SSURGO to generate curve number values for the study area. Topographic data was taken from the USGS National Elevation Database with a 30 meter resolution, as maintaining the same spatial resolution between soil, land cover, and elevation allowed them to eventually be recombined into the intended landscape metrics (Grabowski, Watson, \& Chang 2016).

\subsection{Distance Weighting Tool}

A parametric distance weighting tool was built using an ArcPy workflow that performs three major processes in order to calculate weighted landscape metrics 
(Appendix B). First, the tool delineates subbasin areas above the user-defined observation points. This process follows the standard ArcHydro protocol for subbasin delineation, including the use of stream burning and filling the DEM. Secondly, flow lengths are calculated using the flow length tool available in the Hydro toolset. Total flow lengths are simply determined from this tool, but overland flows are calculated by manipulating the input DEM through the use of a mask that weights stream-defined cells as zero-distance. Lastly, the tool uses array algebra to weight landscape variables based on either of these two flow distance or on the flow accumulation values calculated during subbasin delineation.

All of the above-mentioned weighted metrics utilize the same weighted average equation, in which landscape values for each cell are multiplied by their respective proportional flow distance or flow accumulation values:

$$
\text { Weighted Average }=\frac{\sum x_{i} * w_{i}}{\sum w_{i}}
$$

Where for location $i, x_{i}$ the value of the landscape variable in question, such as elevation or slope, and $w_{i}$ is its respective weight. This general formula was used to create 3 distinct weighting schemes for landscape metrics. The landscape metrics included were elevation (Elev), slope (Slope), percent impervious surface (IMP), curve number (CN), and a metric combining slope and curve number (CN_Slope). Along with non-weighted variables (air temperature, subbasin size, and percent forest cover in $1 \mathrm{~km}$ upstream riparian areas), this allowed for the creation of four different model groups, each using a 
distinct set of landscape variables: (1) aspatial, area average, (2) inverse total flow distance weighted, (2) inverse overland flow distance weighted, (3) proportional flow weighted (Figure 6).

\subsection{Regression Models}

Multiple-linear regressions were constructed in R v. 3.0.2 (R Core Team 2013). Stepwise selection was applied to determine significant predictive variables $(\alpha=0.10)$. Models were constructed for the four dependent stream temperature variables (Mean7dTmax, CV_Tmax, Tmax7d >17.8, and Mean_DTR) and on two different timescales (whole summer and monthly). Subbasin size, stormpipe density, road density, 7-day average maximum daily air temperature, and mean minimum daily air temperature were included in all models prior to backwards selection. The landscape metrics included elevation, slope, Curve Number value, and CN_Slope. These variables were chosen due to data availability and because they have demonstrated a significant influence on stream temperature in other studies (Brown \& Krygier 1970; Booth, Kraseski, \& Jackson 2013; Chang \& Psaris 2013; Grabowski, Watson, \& Chang 2016; Nash et al. 2009).

The performance of the models was compared across two different contexts: (1) the temporal-scale used to quantify stream temperature metrics (whole summer vs. monthly) and (2) the weighting-scheme used to quantify the landscape metrics (Model Groups 1 -4). Initial evaluation of a correlation matrix indicated that the relationships between stream temperature metrics and landscape variables do indeed differ based on the weighting scheme (Figure 7). 
The best-fit model for each timescale and stream temperature metric was determined based on AIC value, which represents the model's predictive power relative to the number of independent variables included. Additionally, VIF values were calculated to ensure that multicollinearity was not significant. The VIF values encountered ranged from 1.12 to 3.08 , indicating little to moderate degrees of multicollinearity. 


\section{Results}

\subsection{Mean 7-Day Average Maximum Temperature}

When Mean7dTmax was calculated for the entire 2011 dry season, all Model

Groups performed moderately well and the lowest $\mathrm{R}^{2}$ value was 0.49 (Table 3). Model 1 demonstrated the best performance with an $\mathrm{R}^{2}$ value of 0.47 . Within this model, percent riparian forest, mean 7-day average maximum air temperature, and all of the area averaged landscape variables (CN, elevation, slope, and CN_Slope) significantly influenced Mean7dTmax. CN and slope were positively associated with Mean7dTmax, while percent riparian forest, 7-day average maximum air temperature, elevation, and CN_Slope were all negatively associated with Mean7dTmax. The negative relationship between 7-day average maximum air temperature and Mean7dTmax was fairly consistent across the dry-season and monthly regression models, which is not only counter intuitive but is also opposite to the correlative relationship (Figure 7). This surprising result could be caused by confounding variables and multicollinearity, which can manifest as coefficient reversal (Kneable \& Dutter 2015).

Alternatively, this surprising relationship between maximum air temperature and stream temperatures could have resulted from the scale at which air temperature data was provided. Because the METDATA is only available from gridded points at a 4-kilometer scale, different stream temperature observation sites often shared the same air temperature data. The use of data at a finer scale could have more accurately captured the relationship between stream temperature and air temperature. Small differences in microclimate could be particularly important because the major processes affecting 
stream temperature are acting at a much smaller scale. One approach of accounting for this small scale variation in climate could involve the inclusion of topographic aspect in the models, which directly the amount of insolation a specific location receives (Johnson \& Wilby 2015).

When Mean7dTmax is modeled separately by month within the dry season, model performance followed a similar trend. For all four months individually, Model 1 outperformed all other Model Groups (Table 3). The only exceptions occurred when monthly Mean7dTmax was not associated with any landscape variables, leading to multiple identical models. For example, Models 1, 2, and 3 for Mean7dTmax in September were identical, as percent riparian forest and road density were found to be significantly associated at this temporal scale. These two relationships were negative and positive, respectively.

\subsection{Average Daily Temperature Range}

Models for Mean_DTR exhibited lower performances than models for the other

three variables. $\mathrm{R}^{2}$ values for dry season models ranged from 0.19 to 0.28 (Table 4). Also, unlike the trends observed between models for the other three variables, dry-season Mean_DTR was almost entirely best predicted by Model Group 3. Overland distance weighted CN, overland distance weighted elevation, and sewer density were positively associated with DT_range. Overland distance weighted slope was negatively associated with DT_range. In terms of the models built at the monthly scale, DT_range followed a 
similar pattern to the other three stream temperature variables. Models in June and July generally outperformed the models for August and September.

\subsection{Coefficient of Variation in Maximum Temperature}

The $\mathrm{R}^{2}$ values for dry season $\mathrm{CV}_{-}$Tmax models ranged from 0.37 to 0.42 and Model 1 best explained the spatial variance in this temperature metric (Table 5). $\mathrm{CN}$ and Slope were both found to positively influence CV_Tmax, while CN_Slope was found to be negatively correlated with CV_Tmax. Surprisingly, the dummy variable for watershed region was not found to be significant, indicating that variations did not significantly differ between the three major watershed categories in respect to the degree to which stream temperatures vary throughout the dry season.

Models built for CV_Tmax at a monthly scale similarly demonstrate that watershed region was not a significant factor. Unlike the models built for seasonal CV_TMax values, the values for some individual months (i.e. June and August) were best indicated by Model Group 3 and 2, respectively. Models for June and July performed better than the models for August and September. In particular, the July Models had the highest $\mathrm{R}^{2}$ values across all of the monthly model groups (Model Group 2, $\mathrm{R}^{2}=0.36$ ).

\subsection{Number of Days Exceeding $17.8^{\circ} \mathrm{C}$}

Models for dry-season $\operatorname{Tmax} 7 \mathrm{~d}>17.8$ demonstrated moderate performance with $\mathrm{R}^{2}$ values that ranged from 0.46 to 0.53 (Table 6). Model 2 performed the best and many variables were found to significantly contribute to $\operatorname{Tmax} 7 \mathrm{~d}>17.8$. Distance weighted CN, 
distance weighted slope, and road density were all positively correlated with Tmax7d>17.8. In contrast, distance weighted elevation, distance weighted CN_Slope, and sewer density were negatively correlated with $\operatorname{Tmax} 7 \mathrm{~d}>17.8$.

Models for individual monthly Tmax7d>17.8 also showed moderate performance. The highest performing model was Model Group 1 for July Tmax7d>17.8 values. Models for June performed relatively poorly, but followed the trend for dry season Tmax $7 \mathrm{~d}>17.8$ as Model Group 2 performed most strongly. The models for August and September values were less successful than those for July. Additionally, because no averaged landscape metrics were found to significantly influence August or September variation, all four model groups were identical. 


\section{Discussion}

\subsection{Distance weighting improved some model performance}

This work builds off of a continued effort to include intuitive information about the properties of the physical landscape and stream system in statistical indicators (Mohseni \& Stefan 1999). Another approach that includes the spatial dimension is the use of geographically weighted techniques incorporating network relationships across the streams within a watershed (Gardner et al. 2003; Ver Hoef et al. 2006). However, because many of the subbasins included in this study are independent, rather than being truly networked, the inclusion of this information many not significantly improve model performance. Rather, this study focused solely on the use of three different distance weighted metrics. Interpretations of the results centered on which distance weighting technique demonstrated the best performance. For example, if weights based on proportional flow accumulation (Model Group 4) performed best, it would indicate that the relative hydrologic activity of a location dictated its influence on stream temperature, a finding which would be supported by past research on other ecological indicators (Wente 2000; Peterson et al. 2011).

The results illustrate mixed usefulness of the distance weighting tool as a means of calculating new landscape metrics for stream temperature studies. The present study investigates a number of different variables that were not included in the previous study using this distance weighting scheme (Grabowski, Watson \& Chang 2016). Interestingly, a number of the variables included in this study regarding temporal variation (CV_Tmax and Mean_DTR) displayed lower model performance values than those used in the 
previous study. Still, for a number of stream temperature metrics and timescales, models that included distance weighted metrics outperformed those that included area averaged metrics. In contrast, for some other stream temperature metrics, no benefit was observed. This was specifically true for Mean7dTmax.

When aggregated on the dry-season as a whole, two out of the four variables were best explained using Model Group 1 (Tables 3, 4, 5, and 6). Mean_DTR was best explained by Model Group 3. As Model Group 3 included the metrics weighted by overland, rather than total, flow distance, this indicates that Mean_DTR may be more heavily influenced by the landscape along the streambank. Because Mean_DTR is controlled at a smaller time scale than the other variables, in particular CV_Tmax, it is affected by the local spatial variation in small scale landscape differences, such as elevation or slope within riparian area. But in terms of model performance, even the best model for dry season Mean_DTR only achieved an $\mathrm{R}^{2}$ value of 0.28 . In contrast, the moderate performance of the seasonal models for Mean7dTmax and Tmax7dEx178 as well as the inclusion of numerous averaged landscape variables illustrate that at the dryseason scale they are significantly tied to the landscape.

\subsection{Monthly-scale model performance}

Models built for stream temperature on a monthly scale further illustrate the usefulness of the distance weighted metrics. Additionally, Model Groups 2 and 3 also gained explanatory power where otherwise Model Group 1 showed an advantage seasonally. These models also demonstrate how the observed relationships between the 
landscape and stream temperature can vary based on temporal scale. For example, while CV_Tmax at the seasonal scale was best explained by the variable included in Model Group 1, on a monthly basis this same stream temperature metric was sometimes best explained by Model Group 3 or 4. Among the models for June CV_Tmax, specifically, Model Group 3 performed best. This interesting contrast demonstrates how the spatial scale at which landscape indicators best explain stream temperatures metrics can vary based on the temporal scale of analysis.

Another trend that emerged through the analysis of the monthly-scale models involves how model strength differed throughout the dry-season. Across all variables, models performed better in the early summer rather than in the late summer. This may indicate that landscape characteristics have a stronger influence on the stream temperature metrics in question during June and July. A possible factor contributing to this effect may be the reduced precipitation and overland flow that tend to occur in late summer, reducing the influence that landscape flow related variables can have on stream temperature. Increased model performance could be achieved through the inclusion of a baseflow variable as baseflow continues to influence stream temperature throughout the year, regardless of precipitation.

Additionally, the decreased explanatory power of the models across summer months could be partially explained by the effects of flow augmentation. In the Tualatin Basin specifically, flow augmentation has been used as a tool to manage summertime stream temperature exceedances. Flow augmentation generally begins mid-summer and increases through the months of August and September (Clean Water Services 2005). 
This action generally has the desired effect of lowering stream temperatures in reaches below the reservoir, which would significantly decrease the explanatory power of any landscape variables included within the models.

\subsection{The differential effects of sewer vs. road density}

Another interesting characteristic of the models resulted from the different influences that sewer and road density appear to have on stream temperatures (Table 7). Barring the models for Mean_DTR, throughout every model that included these one or both of these variables, sewer density was always negatively associated with the stream temperature metric while road density was always had a positive association. This is surprising at first, as both sewer and road density should follow similar spatial patterns, coincident with urban development. Additionally, both road and sewer density could potentially act as pathways for faster transport of runoff into the stream network. However, this finding is somewhat consistent with other previous research. (Sabouri et al. 2013). Together with the extent of development, road density was one of the most significant variables that positively explained the variation in stream temperature in the Piedmont of North Carolina (Somers et al. 2013). Sabouri et al. (2013) also found that sewer density consistently had a negative influence on stream temperatures. This effect could be caused by the shaded and enclosed nature of storm and sewer pipe networks, preventing the infrastructure from warming significantly, in contrast to roads.

Notably, sewer density showed a consistent positive association with Mean_DTR. This indicates that observations with greater range between daily maximums and 
minimums were at least partly explained by the presence of a sewer network. This finding is less surprising because regardless of temperature, the water being conveyed by sewer infrastructure is both temporally inconsistent and released at a point within the stream, rather than gradually and over a broad area. For example, the temporary conveyance of large amounts of runoff into the stream from a storm event can cause a rapid change in stream temperature, which could affect the observed daily range in stream temperatures.

\subsection{Model Residuals}

The residuals from each dry season model were visually and statistically examined for spatial trends in model performance. In general, residuals did not differ in direction between model groups for the same stream temperature metric, but small differences in magnitude were observed at several gaging locations (Table 8). Residuals from the models for dry season Mean7dTmax were relatively small, predominantly ranging between -2 and $+2{ }^{\circ} \mathrm{C}$ (Appendix A.1). Significant overestimation outside of this range generally occurred in the lower Tualatin basin in areas associated with suburban development. Similarly, some significant overestimation occurred in the models for Mean_DTR, specifically in the suburban areas of the lower Tualatin basin, suggesting that the relationship between landscape variables and stream temperature is complicated in newly developed areas.

In contrast, spatial trends were not as clearly straightforward for either CV_Tmax or Tmax7d $>17.8$. Coefficient of variation displayed a relatively small range in over- or 
underestimation, with the extreme values ranging from -6.08 to $+5.08 \%$ (Appendix A.2). Wide variability can be seen in the model residuals for Tmax 7dEx178. Differences in observed and explained number of days in exceedance varied from -58 to +57 days, each respectively representing almost half of the entire dry season period.

Due to the poor or moderate performance of the models in general, as indicated by relatively low $\mathrm{R}^{2}$ values, much of the error associated with the absence of some important explanatory variables, such as baseflow or underlying bedrock geology. Research has suggested that baseflow is an important explanatory variable for stream temperatures, particularly in the dry season (Caissie 2006; Hofmeister et al. 2015). Unfortunately, as is the case with the present study, sufficient streamflow data is not always available to calculate baseflow indices. Nevertheless, a number of the models within this study were still able to reach moderate explanatory power. 


\section{Conclusions}

Regarding the initial research questions, the findings of this study demonstrate that the custom-built ArcPy tool for hydrologic distance weighted has continued to show potential in improving statistical models for stream temperature. This claim is supported by a number of the models at both the seasonal and monthly scale. As described previously, this research builds off of a previous initial study (Grabowski, Watson, \& Chang 2016) and confirms the tool's utility with both an expanded study area and with a number of new stream temperature metrics.

Additionally, the results illustrate how the performance of the distance weighted metrics vary both based on temporal scale and between particular months across the dry season. These variations tended to be specific to the stream temperature metric under investigation. For example area average landscape metrics consistently outperformed distance weighted landscape metrics for all four monthly Mean7dTmax models. In contrast, across the monthly models for CV_Tmax, the explanatory power of distance weighted metrics displayed greater variation based on the particular month. Interestingly, models for all variables showed greater explanatory power in early summer (June and July) and performed more poorly in late summer months (August and September), demonstrating that landscape-stream temperature relationships may be more complex and thus landscape variables may have less of an influence on stream temperatures in late summer. This trend in explanatory power across summer months could be strongly influenced, at least in the Tualatin Basin, by the release of reservoir water from Hagg Lake. 
Although it has been demonstrated that the tool can increase model performance for certain stream temperature metrics, the overall poor to moderate performance of the regression models within this study suggest that a number of key variables are not currently included. The addition of variables for underlying geology or baseflow could greatly enhance model performance. Similarly, a review on stream temperature modelling suggests that incoming solar radiation generally outperforms air temperature metrics when explaining stream temperature variations (Johnson 2003).

Further research should focus on how this tool could be used in the context of explaining variations in other water quality variables at a broader spatial scale. Although the original intention behind this study included the use of a variety of water quality parameters, only stream temperature provided a sufficient number of continuous samples. Other parameters, such as nutrients or sediment, may be more clearly linked with landscape processes, possibly making them better candidates for future use of the distance weighting tool. Many important water quality parameters are linked with both human activity and landscape characteristics, lending the tool to possible applications in modeling the concentrations of a wide variety of other pollutants. 


\section{Tables}

Table 1. Landscape and climate characteristics across the three grouped watersheds illustrating relative differences between the areas.

\begin{tabular}{lrcr}
\hline & Tualatin & Johnson & Clark Co \\
\hline Maximum Elevation (m) & 1066.58 & 344.86 & 956.28 \\
Mean Elevation $(\mathrm{m})$ & 194.88 & 117.28 & 140.12 \\
Minimum Elevation $(\mathrm{m})$ & 16.53 & 3.02 & 6.06 \\
Median Slope $\left({ }^{\circ}\right)$ & 5.00 & 2.00 & 3.00 \\
Mean Slope $\left({ }^{\circ}\right)$ & 8.00 & 4.11 & 4.68 \\
Mean 7DA Max Air Temp $\left({ }^{\circ} \mathrm{C}\right)$ & 23.13 & 23.57 & 22.37 \\
Mean Min Daily Air Temp $\left({ }^{\circ} \mathrm{C}\right)$ & 10.37 & 11.81 & 9.78 \\
Mean Curve Number Value & 71.13 & 81.25 & 69.80 \\
Mean \% Impervious Surface $(\%)$ & 8.89 & 31.88 & 12.63 \\
\hline
\end{tabular}


Table 2. Datasets used to build the regression models, including their descriptive statistics and source information.

\begin{tabular}{|c|c|c|c|c|c|c|c|}
\hline Dataset & $\begin{array}{l}\text { Derived } \\
\text { Variables }\end{array}$ & Timeframe & $\begin{array}{c}\text { Spatial } \\
\text { Resolution }\end{array}$ & Mean & Range & Units & Source \\
\hline \multicolumn{8}{|l|}{$\begin{array}{l}\text { Independent } \\
\text { Variables }\end{array}$} \\
\hline Subbasin Area & & & & 103.4 & $1.5-1,619.5$ & $\mathrm{~km}^{2}$ & $\begin{array}{l}\text { Determined through GIS } \\
\text { processing }\end{array}$ \\
\hline \multirow[t]{2}{*}{ Air Temperature } & $\operatorname{amax} 7$ & $\begin{array}{l}2011 \text { - } \\
\text { Daily }\end{array}$ & $\begin{array}{l}4 \text { kilometers - } \\
\text { gridded points }\end{array}$ & 23.12 & $20.18-23.96$ & ${ }^{\circ} \mathrm{C}$ & $\begin{array}{l}\text { UIdaho METDATA } \\
\text { (Abatzoglou 2011) }\end{array}$ \\
\hline & $\operatorname{amin}$ & & & 10.62 & $8.86-12.94$ & ${ }^{\circ} \mathrm{C}$ & \\
\hline \multirow[t]{2}{*}{ Topography } & elevation & 2002 & $\begin{array}{l}30 \times 30 \text { meter } \\
\text { raster }\end{array}$ & 187.04 & $\begin{array}{l}53.49- \\
589.58\end{array}$ & & USGS NED (Gesch 2002) \\
\hline & slope & & & 7.03 & $1.0-15.13$ & degrees $\left({ }^{\circ}\right)$ & \\
\hline Soil & $\mathrm{CN}$ & 2011 & $\begin{array}{l}30 \times 30 \text { meter } \\
\text { raster }\end{array}$ & & & $\begin{array}{l}\text { hydrologic } \\
\text { soil category }\end{array}$ & $\begin{array}{l}\text { Web Soil Survey (Soil } \\
\text { Survey Staff 2015) }\end{array}$ \\
\hline \multirow[t]{2}{*}{ Land Use } & $\mathrm{CN}$ & 2011 & $\begin{array}{l}30 \times 30 \text { meter } \\
\text { raster }\end{array}$ & 76.34 & $57.26-88.37$ & - & $\begin{array}{l}\text { USGS NLCD (Homer et } \\
\text { al. 2015) }\end{array}$ \\
\hline & perc_for & & & 19 & $0-87$ & $\%$ & \\
\hline Impervious Area & & 2011 & $\begin{array}{l}30 \times 30 \text { meter } \\
\text { raster }\end{array}$ & 30.53 & $7.94-56.47$ & $\%$ & $\begin{array}{l}\text { USGS NLCD (Homer et } \\
\text { al. 2015) }\end{array}$ \\
\hline Road Network & road.dens & 2015 & polyline & 4.87 & $0.79-16.05$ & $\mathrm{~m} / 1000 \mathrm{~m}^{2}$ & $\begin{array}{l}\text { Metro RLIS; City of } \\
\text { Vancouver, WA; City of } \\
\text { Gresham }\end{array}$ \\
\hline Sewer Network & sewer.dens & 2015 & polyline & 2.92 & $0-13.17$ & $\mathrm{~m} / 1000 \mathrm{~m}^{2}$ & $\begin{array}{l}\text { Metro RLIS; City of } \\
\text { Vancouver, WA; City of } \\
\text { Gresham }\end{array}$ \\
\hline
\end{tabular}


Table 2. Continued.

\begin{tabular}{|c|c|c|c|c|c|c|c|}
\hline Dataset & $\begin{array}{l}\text { Derived } \\
\text { Variables }\end{array}$ & Timeframe & $\begin{array}{c}\text { Spatial } \\
\text { Resolution }\end{array}$ & Mean & Range & Units & Source \\
\hline \multicolumn{8}{|l|}{$\begin{array}{l}\text { Dependent } \\
\text { Variables }\end{array}$} \\
\hline \multirow[t]{5}{*}{$\begin{array}{l}\text { Stream } \\
\text { Temperature }\end{array}$} & & $\begin{array}{l}2011- \\
\text { Hourly }\end{array}$ & & & & & $\begin{array}{l}\text { Clean Water Services, City } \\
\text { of Gresham, and WADE }\end{array}$ \\
\hline & Mean7dTmax & & & 17.31 & $11.93-22.61$ & ${ }^{\circ} \mathrm{C}$ & \\
\hline & Mean_DTR & & & 2.13 & $0.05-5.11$ & ${ }^{\circ} \mathrm{C}$ & \\
\hline & CV_Tmax & & & 9.88 & $4.46-16.59$ & $\%$ & \\
\hline & $\operatorname{Tmax} 7 \mathrm{~d}>17.8$ & & & 52.24 & $6-122$ & \# of days & \\
\hline
\end{tabular}


Table 3. Evaluation metrics for regression models predicting mean 7-day average Tmax. Bolded metrics indicate the best model for each timescale, as determined by their respective AIC values. For the months of August and September, landscape variables were often found to be insignificant predictors, resulting in identical models between some of the groups. The four model groups differed based on the calculation of landscape metrics, using (1) area averages, (2) inverse total flow length distance weighting, (3) inverse overland flow length distance weighting, and (4) proportional flow accumulation weighting.

\begin{tabular}{llccccc}
\hline Mean7dTmax & & Summer & June & July & Aug & Sept \\
\hline Model 1 & Adj. R & $\mathbf{0 . 4 7}$ & $\mathbf{0 . 6 3}$ & $\mathbf{0 . 5 3}$ & $\mathbf{0 . 3 7}$ & $\mathbf{0 . 2 8}$ \\
& VIF & $\mathbf{2 . 1 4}$ & $\mathbf{3 . 0 8}$ & $\mathbf{2 . 4 2}$ & $\mathbf{1 . 8 1}$ & $\mathbf{1 . 4 9}$ \\
& AIC & $\mathbf{2 4 1 . 7}$ & $\mathbf{2 2 4 . 3}$ & $\mathbf{2 4 3 . 8}$ & $\mathbf{2 7 0 . 0}$ & $\mathbf{2 3 2 . 2}$ \\
Model 2 & Adj. R & 0.45 & 0.60 & 0.50 & $\mathbf{0 . 3 7}$ & $\mathbf{0 . 2 8}$ \\
& VIF & 2.03 & 2.78 & 2.26 & $\mathbf{1 . 8 1}$ & $\mathbf{1 . 4 9}$ \\
& AIC & 243.2 & 229.2 & 246.2 & $\mathbf{2 7 0 . 0}$ & $\mathbf{2 3 2 . 2}$ \\
Model 3 & Adj. R & 0.39 & 0.52 & 0.39 & 0.30 & $\mathbf{0 . 2 8}$ \\
& VIF & 1.76 & 2.20 & 1.74 & 1.53 & $\mathbf{1 . 4 9}$ \\
& AIC & 246.7 & 238.6 & 257.5 & 272.9 & $\mathbf{2 3 2 . 2}$ \\
Model 4 & Adj. R & 0.45 & 0.55 & 0.49 & 0.34 & 0.25 \\
& VIF & 1.99 & 2.39 & 2.15 & 1.63 & 1.41 \\
& AIC & 242.6 & 235.2 & 247.7 & 270.8 & 234.0 \\
\hline
\end{tabular}


Table 4. Evaluation metrics for regression models predicting Mean_DTR. Bolded metrics indicate the best model for each timescale, as determined by their respective AIC values. The four model groups differed based on the calculation of landscape metrics, using (1) area averages, (2) inverse total flow length distance weighting, (3) inverse overland flow length distance weighting, and (4) proportional flow accumulation weighting.

\begin{tabular}{llccccc}
\hline Mean_DTR & & Summer & June & \multicolumn{1}{l}{ July } & Aug & Sept \\
\hline Model 1 & Adj. R & 0.19 & 0.26 & 0.19 & 0.17 & 0.13 \\
& VIF & 1.34 & 1.46 & 1.38 & 1.31 & 1.19 \\
& AIC & 175.1 & 159.0 & 192.2 & 199.2 & 171.5 \\
Model 2 & & & & & & \\
& Adj. R & 0.25 & 0.24 & 0.27 & $\mathbf{0 . 2 4}$ & 0.18 \\
& VIF & 1.52 & 1.42 & 1.55 & $\mathbf{1 . 4 9}$ & 1.39 \\
& AIC & 172.9 & 160.4 & 186.3 & $\mathbf{1 9 6 . 6}$ & 173.2 \\
Model 3 & & & & & & \\
& Adj. R & $\mathbf{0 . 2 8}$ & $\mathbf{0 . 3 0}$ & $\mathbf{0 . 2 7}$ & 0.19 & $\mathbf{0 . 2 3}$ \\
& VIF & $\mathbf{1 . 5 5}$ & $\mathbf{1 . 6 1}$ & $\mathbf{1 . 5 4}$ & 1.35 & $\mathbf{1 . 4 5}$ \\
& AIC & $\mathbf{1 6 9 . 7}$ & $\mathbf{1 5 6 . 5}$ & $\mathbf{1 8 5 . 0}$ & 197.6 & $\mathbf{1 6 8 . 4}$ \\
& & & & & & \\
Model 4 & Adj. R & 0.20 & 0.24 & 0.20 & 0.10 & 0.17 \\
& VIF & 1.35 & 1.42 & 1.34 & 1.15 & 1.29 \\
& AIC & 174.6 & 160.4 & 188.1 & 201.8 & 170.3 \\
\hline
\end{tabular}


Table 5. Evaluation metrics for regression models predicting CV_Tmax. Bolded metrics indicate the best model for each timescale, as determined by their respective AIC values. The four model groups differed based on the calculation of landscape metrics, using (1) area averages, (2) inverse total flow length distance weighting, (3) inverse overland flow length distance weighting, and (4) proportional flow accumulation weighting.

\begin{tabular}{llccccc}
\hline CV_Tmax & & Summer & June & July & Aug & Sept \\
\hline Model 1 & Adj. R & $\mathbf{0 . 4 2}$ & 0.29 & $\mathbf{0 . 3 8}$ & 0.20 & $\mathbf{0 . 1 1}$ \\
& VIF & $\mathbf{1 . 8 1}$ & 1.48 & $\mathbf{1 . 7 2}$ & 1.36 & $\mathbf{1 . 1 6}$ \\
& AIC & $\mathbf{2 6 0 . 5}$ & 215.8 & $\mathbf{2 2 1 . 8}$ & 220.4 & $\mathbf{2 6 9 . 9}$ \\
Model 2 & Adj. R & 0.40 & 0.27 & 0.39 & $\mathbf{0 . 2 1}$ & 0.09 \\
& VIF & 1.78 & 1.45 & 1.77 & $\mathbf{1 . 3 6}$ & 1.15 \\
& AIC & 263.4 & 217.5 & 221.9 & $\mathbf{2 2 0 . 1}$ & 272.4 \\
Model 3 & Adj. R & 0.40 & $\mathbf{0 . 3 6}$ & 0.37 & 0.20 & 0.10 \\
& VIF & 1.84 & $\mathbf{1 . 6 9}$ & 1.72 & 1.40 & 1.16 \\
& AIC & 265.3 & $\mathbf{2 1 1 . 4}$ & 224.0 & 222.3 & 271.8 \\
Model 4 & Adj. R & 0.37 & 0.28 & 0.32 & 0.20 & 0.10 \\
& VIF & 1.75 & 1.49 & 1.60 & 1.36 & 1.12 \\
& AIC & 268.7 & 217.5 & 228.8 & 220.4 & 270.1 \\
\hline
\end{tabular}


Table 6. Evaluation metrics for regression models predicting number of days that 7-day average Tmax exceeded $17.8^{\circ} \mathrm{C}$. Bolded metrics indicate the best model for each timescale, as determined by their respective AIC values. For the months of both August and September, no landscape variables were selected as significant, resulting in identical models between the four model groups. The four model groups differed based on the calculation of landscape metrics, using (1) area averages, (2) inverse total flow length distance weighting, (3) inverse overland flow length distance weighting, and (4) proportional flow accumulation weighting.

\begin{tabular}{llccccc}
\hline Tmax7d $>\mathbf{1 7 . 8}$ & & Summer & \multicolumn{1}{l}{ June } & July & Aug & Sept \\
\hline Model 1 & Adj. $\mathbf{R}^{2}$ & 0.51 & 0.29 & $\mathbf{0 . 5 4}$ & 0.39 & 0.32 \\
& VIF & 2.39 & 1.48 & $\mathbf{2 . 5 4}$ & 1.74 & 1.61 \\
\multirow{3}{*}{ Model 2 } & AIC & 618.5 & 401.0 & $\mathbf{4 5 9 . 5}$ & 461.7 & 418.8 \\
& Adj. $\mathrm{R}^{2}$ & $\mathbf{0 . 5 3}$ & $\mathbf{0 . 3 3}$ & 0.51 & 0.39 & 0.32 \\
& VIF & $\mathbf{2 . 5 0}$ & $\mathbf{1 . 6 4}$ & 2.38 & 1.74 & 1.61 \\
\multirow{3}{*}{ Model 3 } & AIC & $\mathbf{6 1 7 . 4}$ & $\mathbf{3 9 9 . 9}$ & 463.9 & 461.7 & 418.8 \\
& Adj. $\mathrm{R}^{2}$ & 0.45 & 0.22 & 0.48 & 0.39 & 0.32 \\
& VIF & 1.94 & 1.37 & 2.14 & 1.74 & 1.61 \\
& AIC & 622.3 & 407.8 & 466.8 & 461.7 & 418.8 \\
& Adj. $\mathrm{R}^{2}$ & 0.49 & 0.15 & 0.50 & 0.39 & 0.32 \\
& VIF & 2.18 & 1.19 & 2.24 & 1.74 & 1.61 \\
& AIC & 620.6 & 410.9 & 463.8 & 461.7 & 418.8 \\
\hline
\end{tabular}


Table 7. Coefficients values from regression models for whole summer stream temperature metrics. The variables fJohnson and fTualatin are the factor dummy variables for watershed group. The four model groups differed based on the calculation of landscape metrics, using (1) area averages, (2) inverse total flow length distance weighting, (3) inverse overland flow length distance weighting, and (4) proportional flow accumulation weighting.

\begin{tabular}{|c|c|c|c|c|c|c|c|c|c|c|c|c|}
\hline Mean7dTmax & Intercept & Size & fJohnson & fTualatin & road.dens & sewer.dens & Perc_For & 7dAmax & $\mathrm{CN}$ & Elev & Slope & CN_Slope \\
\hline Model 1 & 25.34 & & 2.56 & 2.17 & & & -2.33 & -0.93 & 0.17 & -0.01 & 1.06 & -0.01 \\
\hline Model 2 & 28.86 & & 3.42 & 2.13 & & & & -1.32 & 0.24 & -0.02 & 1.77 & -0.02 \\
\hline Model 3 & 15.30 & & 1.93 & 1.86 & 0.17 & & -2.30 & & & & & \\
\hline Model 4 & 32.26 & & 3.36 & 2.47 & 0.13 & & & -0.94 & 0.06 & -0.01 & & \\
\hline
\end{tabular}

\begin{tabular}{|c|c|c|c|c|c|c|c|c|c|c|c|c|}
\hline Range_DTR & Intercept & Size & fJohnson & fTualatin & road.dens & sewer.dens & Perc_For & 7dAmax & $\mathrm{CN}$ & Elev & Slope & CN_Slope \\
\hline Model 1 & -0.72 & $-1.16 \mathrm{E}-09$ & & & & & & -0.31 & 0.12 & & 0.76 & -0.01 \\
\hline Model 2 & 10.37 & $-1.03 \mathrm{E}-09$ & 1.29 & 0.14 & & & & -0.88 & 0.16 & -0.01 & 1.55 & -0.02 \\
\hline Model 3 & -6.74 & $-1.42 \mathrm{E}-09$ & 0.73 & -0.05 & & 0.10 & & & 0.10 & 1.51 & -0.02 & \\
\hline Model 4 & 11.65 & $-8.59 \mathrm{E}-10$ & 0.92 & 0.44 & & 0.06 & & -0.44 & & & & \\
\hline
\end{tabular}

\begin{tabular}{|c|c|c|c|c|c|c|c|c|c|c|c|c|}
\hline CV_Tmax & Intercept & Size & fJohnson & fTualatin & road.dens & sewer.dens & Perc_For & 7dAmax & $\mathrm{CN}$ & Elev & Slope & CN_Slope \\
\hline Model 1 & -7.67 & & & & & & & & 0.19 & & 1.98 & -0.02 \\
\hline Model 2 & 6.37 & & & & & & & -0.67 & 0.22 & & 2.54 & -0.03 \\
\hline Model 3 & 18.80 & & 2.02 & 1.83 & & & & -1.08 & 0.18 & 2.64 & -0.04 & \\
\hline Model 4 & 27.83 & & 2.21 & 2.11 & & & & -1.50 & 0.19 & & 3.12 & -0.04 \\
\hline
\end{tabular}


Table 7. Continued.

\begin{tabular}{lrrrrrrrrrrrr}
\hline 7dTmax>17.8 & Intercept & Size & fJohnson & fTualatin & road.dens & sewer.dens & Perc_For & 7dAmax & CN & Elev & Slope & CN_Slope \\
\hline Model 1 & 15.31 & 38.18 & 43.13 & 8.03 & -4.96 & -42.20 & -10.79 & 3.03 & & 17.38 & -0.24 \\
Model 2 & 160.86 & 50.52 & 30.93 & 7.61 & -5.00 & -37.66 & -22.50 & 4.84 & -0.34 & 40.25 & -0.49 \\
Model 3 & 16.81 & 35.57 & 29.83 & 3.50 & & -45.65 & & & & & & \\
Model 4 & 239.76 & 45.24 & 49.46 & 9.17 & -4.89 & & -13.63 & 0.94 & & -0.07 \\
\hline
\end{tabular}

Abbreviations for explanatory variables: fJohnson and fTualatin = dummy variables for subbasin group, road.dens $=\operatorname{road~density~}\left(\mathrm{m} / \mathrm{km}^{2}\right)$, sewer.dens $=$ sewer/storm pipe density $\left(\mathrm{m} / \mathrm{km}^{2}\right)$, Perc_For $=$ percent forest in riparian buffer, 7dAmax $=$ mean 7-day average maximum air temperature, $\mathrm{CN}=$ Curve Number, Elev = elevation, CN_Slope = curve number multiplied by slope. 
Table 8. Moran's I and p-values (in parentheses) for the residuals from each model, indicating that only one of the models' residuals are spatially autocorrelated at an alpha level of $0.05(*)$. Model 2 for dry-season Tmax $7 \mathrm{~d}>17.8$ displayed statistically significant, but very weak negative autocorrelation. The four model groups differed based on the calculation of landscape metrics, using (1) area averages, (2) inverse total flow length distance weighting, (3) inverse overland flow length distance weighting, and (4) proportional flow accumulation weighting.

\begin{tabular}{lcccc}
\hline & Mean7dTmax & Mean_DTR & CV_Tmax & Tmax7d >17.8 \\
\hline Model 1 & $-0.015(0.55)$ & $-0.015(0.50)$ & $-0.028(0.72)$ & $-0.018(0.08)$ \\
Model 2 & $-0.016(0.30)$ & $-0.013(0.49)$ & $-0.014(0.82)$ & $-0.012(0.02) *$ \\
Model 3 & $-0.014(0.55)$ & $-0.015(0.91)$ & $-0.015(0.67)$ & $-0.019(0.21)$ \\
Model 4 & $-0.014(0.34)$ & $-0.018(0.60)$ & $-0.023(0.65)$ & $-0.020(0.06)$ \\
\hline
\end{tabular}


Figures

Figure 1. Conceptual diagram illustrating the main processes that can influence stream temperature.

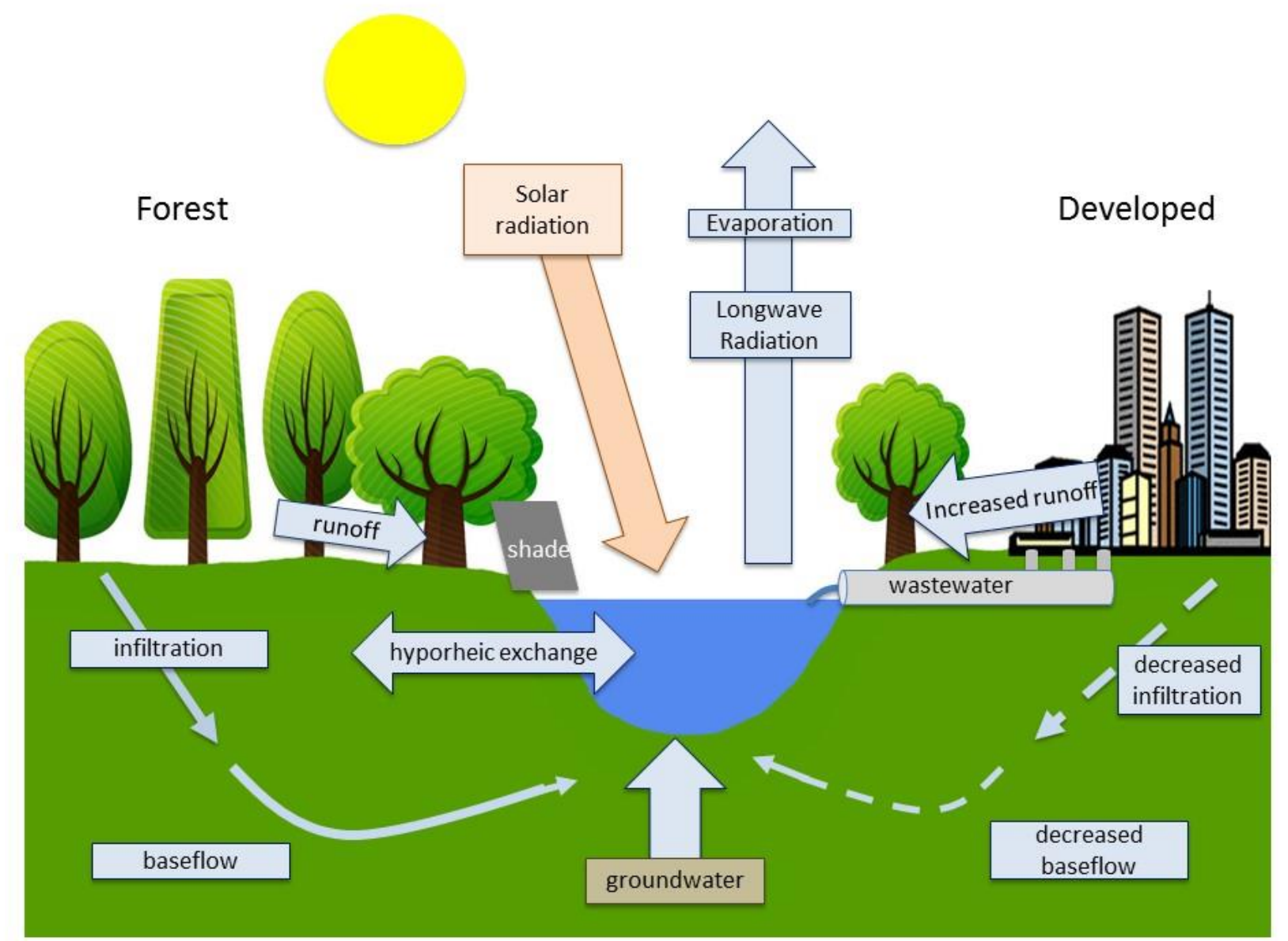


Figure 2. Locations of stream temperature observation sites within the study area.

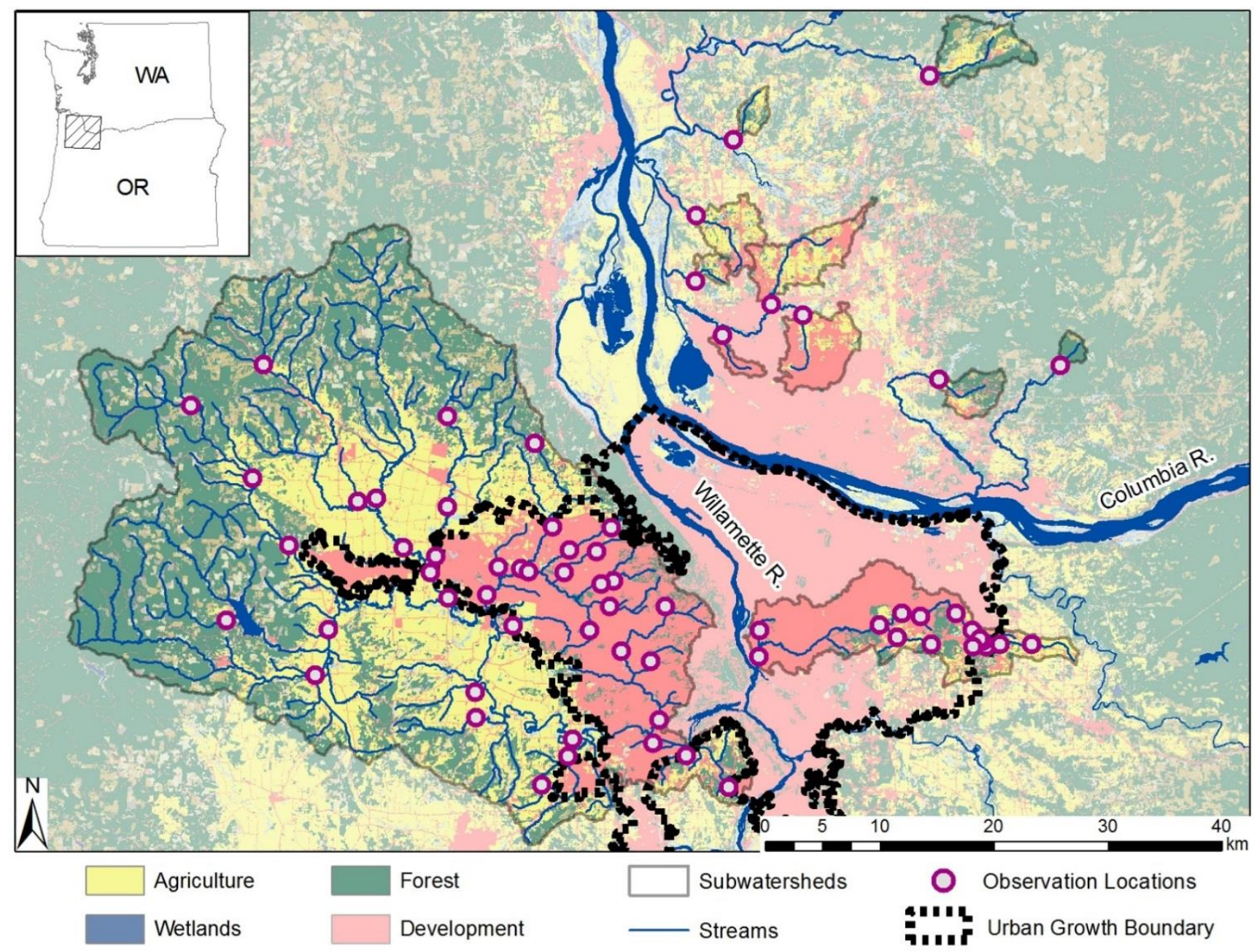


Figure 3. Climograph of monthly averages of mean daily air temperature (line) and total precipitation (bars). The data was taken from a UIdaho location at the mouth of Johnson Creek for the period 1979-2015 (Abatzoglou 2011).

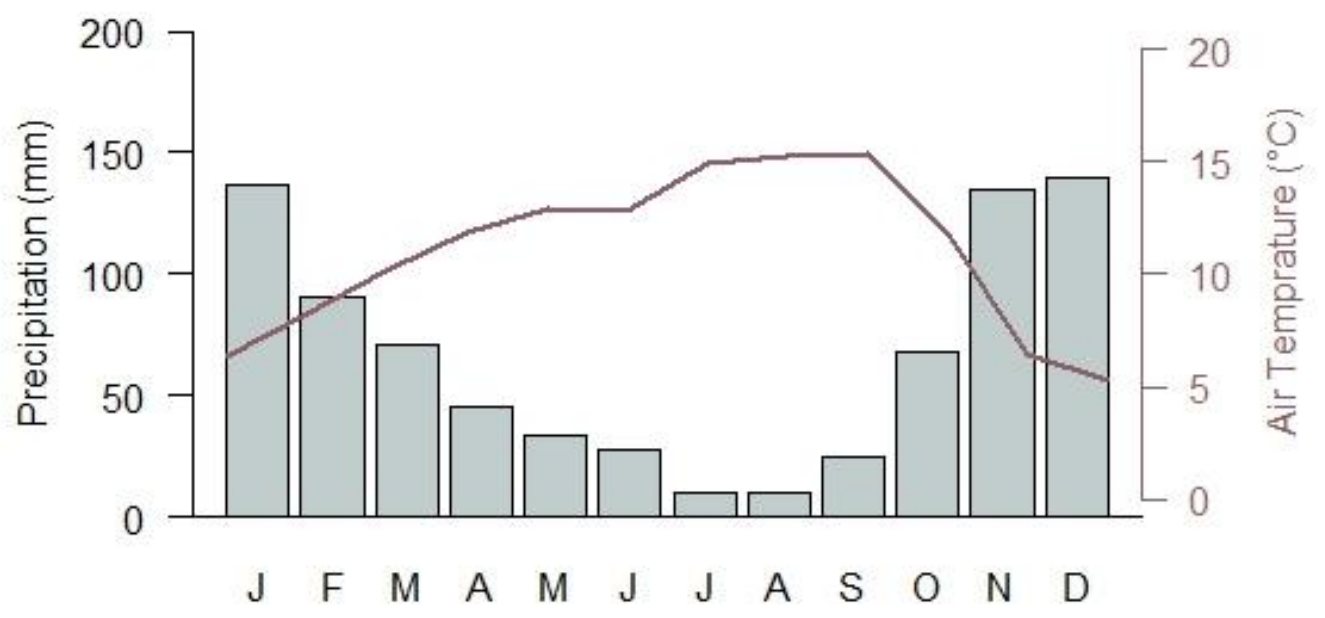


Figure 4. Difference in mean 7-day average Tmax variation acros the three watershed regions

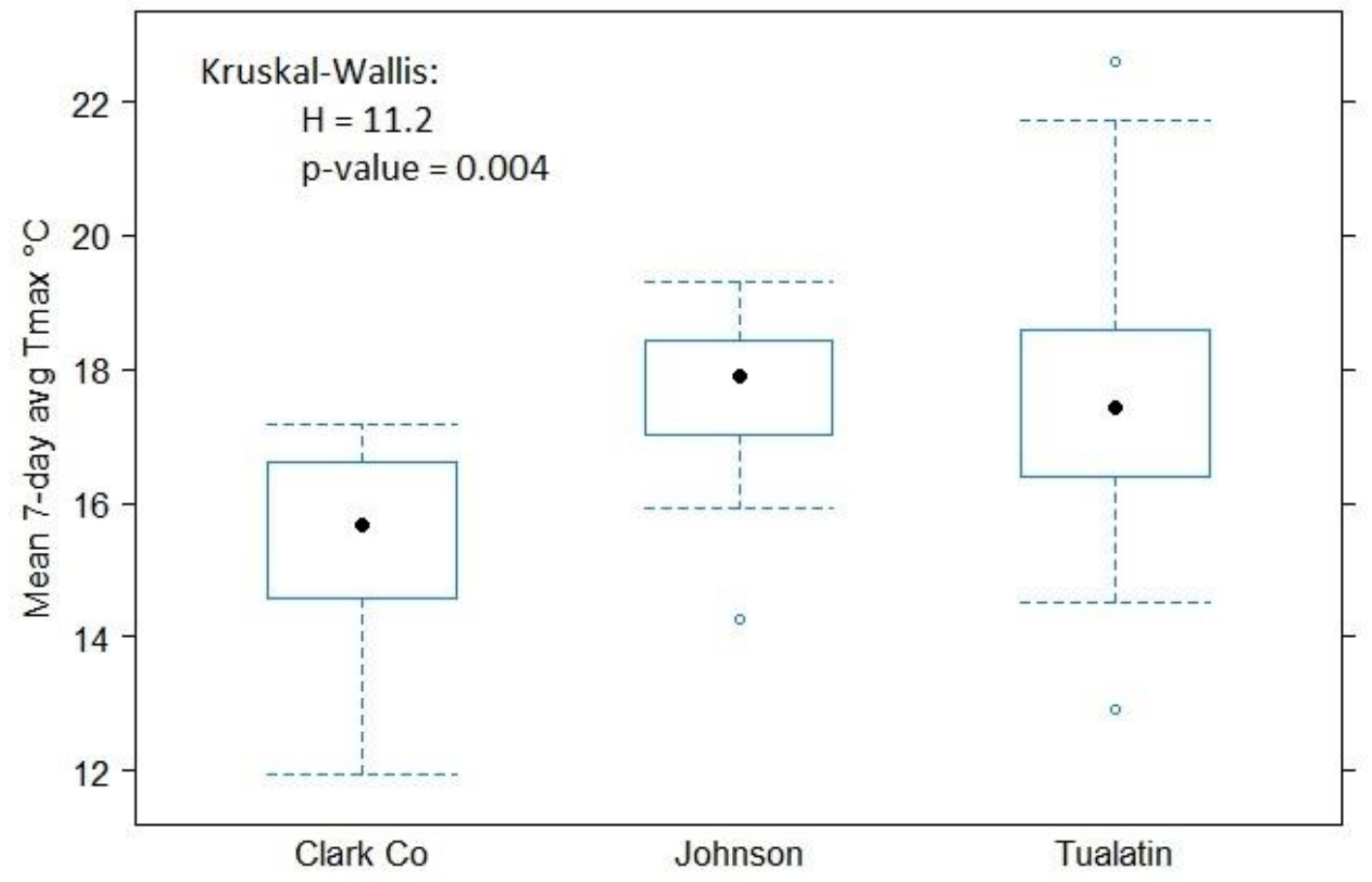


Figure 5. Spatial variation of stream temperature metrics quantified at the seasonal scale.

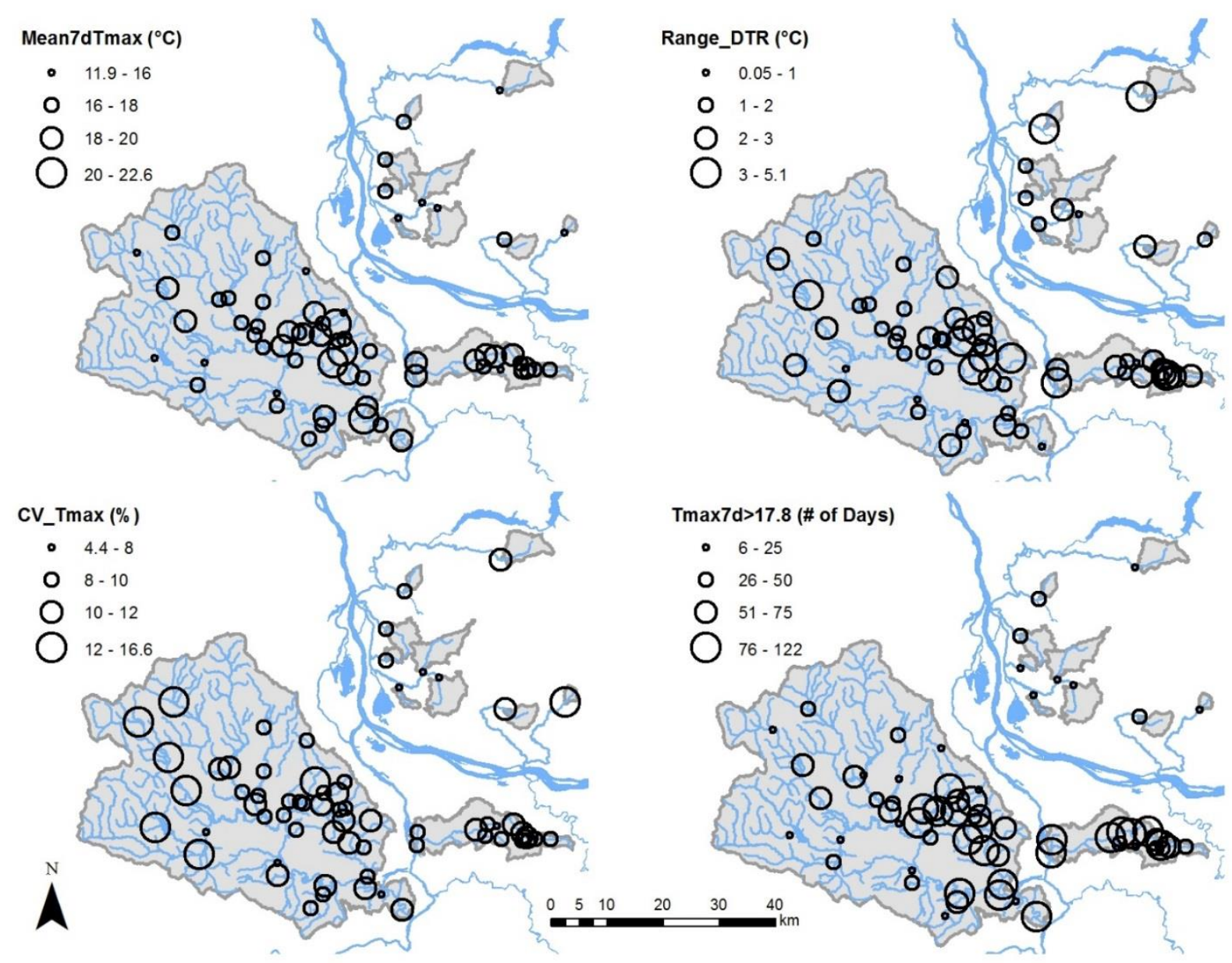


Figure 6. A conceptual diagram illustrating how landscape metrics vary based on the four averaging techniques.

\section{Delineated Subwatershed:}

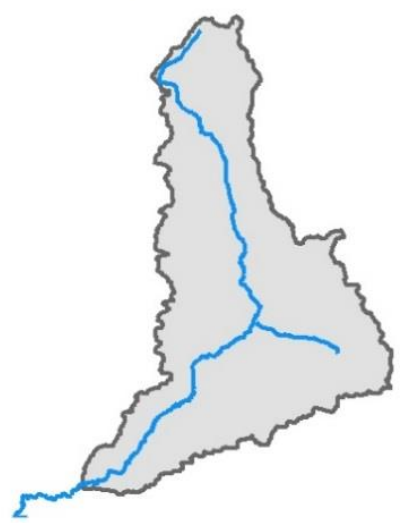

\section{Distance Layers Used for Weighting:}

Total Flow Length

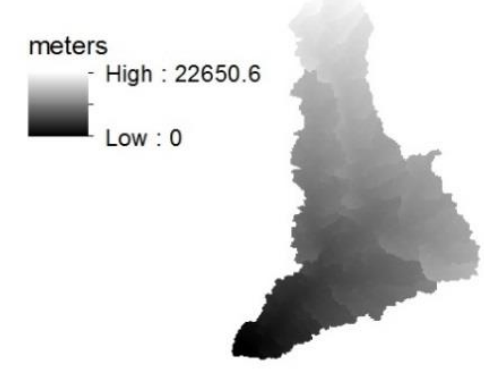

IDW_CN:

85.9

\section{Overland Flow Length}

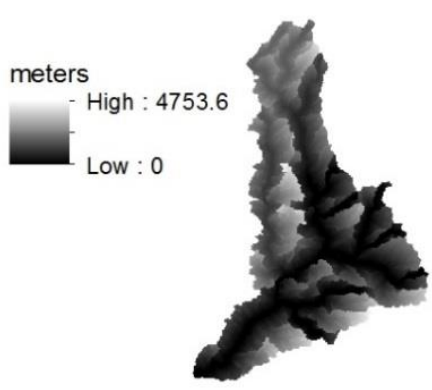

IDW_CN_OL:

83.3

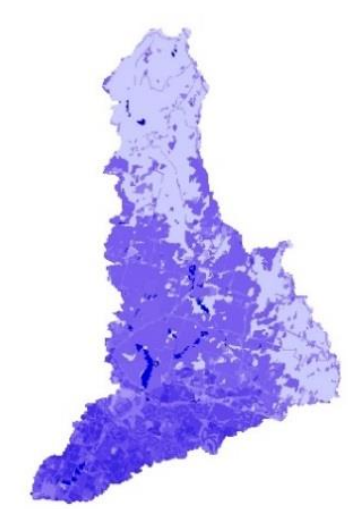

Flow Accumulation

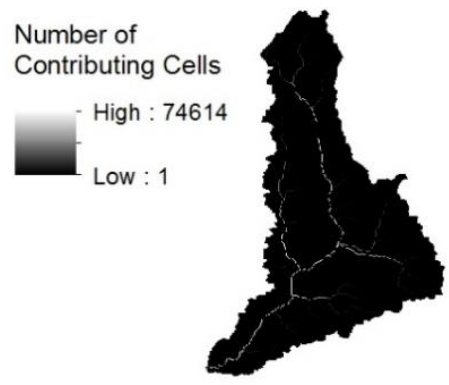

PFAw_CN:

86.8 
Figure 7. Correlation matrix for whole summer stream temperature metrics and the predictive variables included. The two halves of the matrix display the correlations graphically using graduated circles and $r$ values respectively.

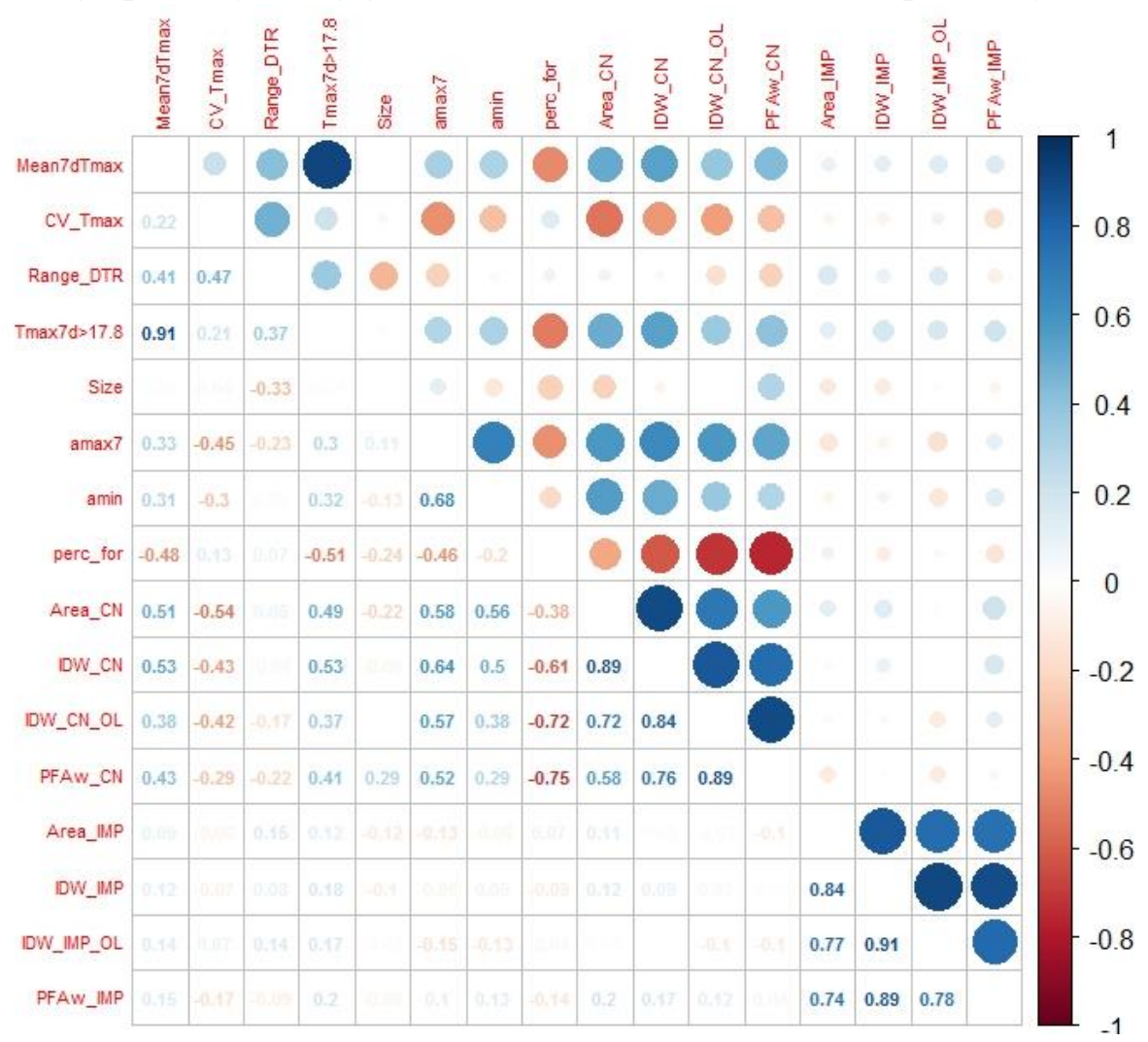

Abbreviations for variables: Mean7dTmax = mean 7-day average maximum stream temperature, CV_Tmax = coefficient of variation of maximum stream temperature, Range_DTR $=$ mean daily stream temperature range, Tamx $7 \mathrm{~d}>17.8=$ number of days stream temperature exceeded $17.8{ }^{\circ} \mathrm{C}$, amax $7=$ mean 7-day average maximum air temperature, amin $=$ mean minimum air temperature, perc_for $=$ percent of riparian area forested, Area[x] = area average, IDW_[x] = inverse total flow length weighted, IDW_[x]_OL = inverse overland flow length weighted, PFAw_[x] = proportional flow accumulation weighted, $\mathrm{CN}=$ curve number, IMP = percent impervious area. 


\section{References}

Abatzoglou, J.T. 2011. Development of gridded surface meteorological data for ecological applications and modelling. International Journal of Climatology. DOI: $10.1002 /$ joc.3413.I

Ahilan, S., M. Guan, A. Sleigh, N. Wright, and H. Chang. 2016. The influence of floodplain restoration on sediment dynamics in an urban river. Journal of Flood Risk Management. DOI: 10.1111/jfr3.12251

Allan, J.D. 2004. Landscapes and riverscapes: The influence of land use on stream ecosystems. Annual Review of Ecology 35: 257-284.

Arnold, C.L. and C.J. Gibbons. 1996. Impervious surface coverage: The emergence of a key environmental indicator. Journal of the American Planning Association 62: 243-258.

Baker, E.A., K.E. Wehrly, P.W. Seelbach, L. Wang, M.J. Wiley, and T. Simon. 2005. A multimetric assessment of stream condition in the northern lakes and forests ecoregion using spatially explicit statistical modeling and regional normalization. Transactions of the American Fisheries Society 134: 697-710.

Battin, J., M.W. Wiley, M.H. Ruckelshaus, R.N. Palmer, E. Korb, K.K. Bartz, and H. Imaki. 2007. Projected impacts of climate change on salmon habitat restoration. Proceedings of the National Academy of Sciences 104: 6720-6725.

Booth, D.B., K.A. Kraseski, and C.R. Jackson. 2013. Local-scale and watershed-scale determinants of summertime urban temperatures. Hydrological Processes 28(4): 2427-2438. 
Boyd, M. and D. Sturdevant. 1997. The scientific basis for Oregon's stream temperature standard: Common questions and straight answers. Portland, Oregon: Oregon Department of Environmental Quality.

Brown, G.W. and J.T. Krygier. 1970. Effects of clear-cutting on stream temperature. Water Resources Research 6: 1133-1139.

Buck, O., D.K. Niyogi and C.R. Townsend. 2004. Scale-dependence of land use effects on water quality of streams in agricultural catchments. Environmental Pollution 130(2): 287-299.

Caissie, D. 2006. The thermal regime of rivers: a review. Freshwater Biology 51: 13891406.

Chang, H. 2008. Spatial analysis of water quality trends in the Han River basin, South Korea. Water Research 42: 3285-3304.

Chang, H. and M. Psaris. 2013. Local landscape predictors of maximum stream temperature and thermal sensitivity in the Columbia River Basin, USA. Science of the Total Environment 461-462: 587-600.

Chang, H., P. Thiers, N.R. Netsuil, A. Yeakley, G. Rollwagen-Bolen, S. Bolen, and S. Singh. 2014. Relationships between environmental governance and water quality in growing metropolitan areas: A synthetic view through the coupled natural and human systems lens. Hydrology and Earth System Sciences 18: 1383-1395.

Clean Water Services. 2005. Revised Temperature Management Plan. 163 p. Available at https://www.cleanwaterservices.org/media/1479/temperature-managementplan.pdf 
Cochran, B. and C. Logue. 2011. A watershed approach to improve water quality: Case study of Clean Water Services' Tualatin River Program. Journal of the American Water Resources Association 47(1): 29-38.

Cooper, S.D., S. Diehl, K. Kratz, and O. Sarnelle. 1998. Implications of scale for patterns and processes in stream ecology. Australian Journal of Ecology 23: 27-40.

Cox, B.A. 2003. A review of dissolved oxygen modelling techniques for lowland rivers. Science of The Total Environment 314-316: 303-334.

Degenhardt, D.A. and C.C. Fromuth. 1993. Monitoring the Tualatin River Basin to assess the effectiveness of the Oregon Forest Practices Program: Preliminary results of phosphorus monitoring. Environmental Monitoring and Assessment 26: 235-247.

Gardner, B., P.J. Sullivan, and A.J. Lembo Jr. 2003. Predicting stream temperatures: Geostatistical model comparison using alternative distance metrics. Canadian Journal of Fish and Aquatic Sciences 60(3): 344-351.

Gesch, D., M. Oimoen, S. Greenlee, C. Nelson, M. Steuck, and D. Tyler, 2002. The National Elevation Dataset. Photogramm. Eng. Rem. S., 68(1), 5-11.

Gove, N.E., R.T. Edwards, and L.L. Conquest. 2007. Effects of scale on land use and water quality relationships: A longitudinal basin-wide perspective. Journal of the American Water Resources Association 37(6): 1721-1734.

Grabowski, Z., E. Watson, and H. Chang. 2016. Using spatially explicit indicators to investigate watershed characteristics and stream temperature relationships. Science of the Total Environment 551-552: 376-386. 
Herlihy, A.T., J.L. Stoddard and C.B. Johnson. 1998. The relationship between stream chemistry and watershed land cover data in the mid-Atlantic Region, U.S. Water, Air and Soil Pollution 105: 377-386.

Hofmeister, K.L., C..M. Clanfrani, and H.W. Cully. 2015. Complexities in the stream temperature regime of a small mixed-used watershed, Blacksburg, VA.

Ecological Engineering 78: 101-111.

Holtby, L.B., T.E. McMahon, and J.C. Scrivener. 1989. Stream temperatures and interannual variability in the emigration timing of Coho salmon (Oncorhynchus kistuch) smolts and fry and Chum salmon (O. Keta) fry from Carnation Creek, British Columbia. Canadian Journal of Fish and Aquatic Science 46: 1396-1405.

Homer, C.G., J.A. Dewitz, L. Yang, S. Jin, P. Danielson, G. Xian, J. Coulston, N.D. Herold, J.D. Wickham, and K. Megown. 2015. Completion of the 2011 National Land Cover Database for the conterminous United States - Representing a decade of land cover change information. Photogrammetric Engineering and Remote Sensing 84(5): 345-354.1

Hoyer, W. and H. Chang. 2014. Development of future land cover change scenarios in the metropolitan fringe, Oregon, U.S., with stakeholder involvement. Land 3(1): $322-341$.

Hunsaker, C.T. and D.A. Levine. 1995. Hierarchical approaches to the study of water quality in rivers. BioScience 45: 193-202.

Hurley, T. and A. Mazumder. Spatial scale of land-use impacts on riverine drinking source water quality. Water Resources Research 49: 1591-1601. 
Hynes, H.B.N. 1970. Ecological factors affecting fishes. In The Ecology of Running Waters, 319-341. Toronto: University of Toronto Press.

Johnson, S.L. 2003. Stream temperature: scaling of observations and issues for modelling. Hydrological Processes 17: 497-499.

Johnson, S.L. 2004. Factors influencing stream temperatures in small streams: substrate effects and a shading experiment. Canadian Journal of Fish and Aquatic Sciences 61: 913-923.

Johnson, L.B., C. Richards, G.E. Host, and J.W. Arthur. 1997. Landscape influences on water chemistry in Midwestern stream ecosystems. Freshwater Biology 37: 193208.

Johnson, M.F. and R.L. Wilby. 2015. Seeing the landscape for the trees: Metrics to guide riparian shade management in river catchments. Water Resources Research 51(5): 3754-3769.

King, R.S., M.E. Baker, D.F. Whigham, D.E. Weller, T.E. Jordan, P.F. Kazyak, and M.K. Hurd. 2005. Spatial considerations for linking watershed land cover to ecological indicators in streams. Ecological Applications 15: 137-153.

Knaeble, B. and S. Dutter. 2015. Reversals of least-squares estimates and modelindependent estimation for directions of unique effects. Cornell University. arXiv index: 1503.02722 .

Lee, K.K. and D.T. Snyder. 2009. Hydrology of the Johnson Creek basin, Oregon. U.S. Geological Survey Scientific Investigations Report 2009-5123, 56 p.

Lichatowich, J.A. 1999. Salmon without rivers. Washington, DC: Island Press. 
Mohseni, O. and H.G. Stefan. 1999. Stream temperature/air temperature relationship: A physical interpretation. Journal of Hydrology 218(3): 129-141.

Nash, M.S., D.T. Heggan, D. Ebert, T.G. Wade, and R.K. Hall. 2009. Multi-scale landscape factors influencing stream water quality in the state of Oregon. Environmental Monitoring and Assessment 156: 343-360.

Nelson, K.C. and M.A. Palmer. 2007. Stream temperature surges under urbanization and climate change: Data, models, and responses. Journal of the American Water Resources Association 43(2): 440-452.

Nielson, L. and C.L. Smith. 2005. Influences on residential yard care and water quality: Tualatin Watershed, Oregon. Journal of the American Water Resources Association 41: 93-106.

Oregon Department of Environmental Quality. 2001. Tualatin Subbasin Total Maximum Daily Load (TMDL). Technical Report.

Peterson, E.E., F. Sheldon, R. Darnell, S.E. Bunn, and B.D. Harch. 2011. A comparison of spatially explicit landscape representation methods and their relationship to stream condition. Freshwater Biology 56: 590-610.

Poole, G.C. and C.H. Berman. 2001. An ecological perspective on in-stream temperature: Natural heat dynamics and mechanisms of human-caused thermal degradation. Environmental Management27: 787-802.

Pratt, B. and H. Chang. 2012. Effects of land cover, topography, and built structure on seasonal water quality at multiple spatial scales. Journal of Hazardous Materials 209;210: 48-58. 
R Core Team. 2013. R: A language and environment for statistical computing. $\mathrm{R}$ Foundation for Statistical Computing, Vienna, Austria. Available at http://www.R-project.org/

Ramirez, A., K.G. Rosas, A.E. Lugo, and O.M. Ramos-Gonzalez. 2014. Spatio-temporal variation in stream water chemistry in a tropical urban watershed. Ecology and Society 19(2): 45.

Richter, A. and S.A. Kolmes. 2005. Maximum temperature limits for Chinook, Coho, and Chum salmon, and Steelhead trout in the Pacific Northwest. Reviews in Fisheries Science 13: 23-49.

Sabouri, F., B. Gharabaghi, A.A. Mahboubi, and E.A. McBean. 2013. Impervious surfaces and sewer pipe effects on stormwater runoff temperature. Journal of Hydrology 502: 10-17.

Sawyer, J.A., P.M. Stewart, M.M. Mullen, T.P. Simon, and H.H. Bennett. 2004. Influence of habitat, water quality, and land use on macro-invertebrate and fish assemblages of a southern coastal plain watershed, USA. Aqautic Ecosystem Health \& Management\& 7(1), 85-99.

Schuft, M.J., T.J. Moser, P.J. Wigington, D.L. Stevens, L.S. McAllister, S.S. Chapman, and T.L. Ernst. 1999. Development of landscape metrics for characterizing riparian-stream networks. Photogrammetric Engineering \& Remote Sensing 65: 1157-1167.

Shandas, V. and M. Alberti. 2009. Exploring the role of vegetation fragmentation on aquatic conditions: Linking upland with riparian areas in Puget Sound lowland streams. Landscape and Urban Planning 90: 66-75. 
Silva, L. and D.D. Williams. 2001. Buffer zone versus whole catchment approaches to studying land use impact on river water quality. Water Research 35: 3462-3472.

Soil Survey Staff, Natural Resources Conservation Service, United States Department of Agriculture. Soil Survey Geographic (SSURGO) Database for Northwest Oregon. Available: http://soildatamart.nrcs.usda.gov (accessed 11/25/2013).

Somers, K.A., E.S. Bernhardt, J.B. Grace, B.A. Hassett, E.B. Sudduth, S. Wang, and D.L. Urban. 2013. Streams in the urban heat island: spatial and temporal variability in temperature. Freshwater Science 32: 309-326.

Sponseller, R.A., E.F. Benfield, and H.M. Valett. 2001. Relationships between land use, spatial scale and stream macroinvertebrate communities. Freshwater Biology 46: 1409-1424.

Stohr, A., T.C. Cummings, and K. McKee. 2011. Salmon Creek temperature total maximum daily load: Water quality improvement report and implementation plan [Washington State Department of Ecology Technical Release, publication no. 1110-044].

U.S. Department of Agriculture. 1986. Urban hydrology for small watersheds [Technical Release, no. 55]. Retrieved from http://www.nrcs.usda.gov/Internet/FSE_DOCUMENTS/stelprdb1044171.pdf

U.S. Environmental Protection Agency, in partnership with the U.S. Geological Survey. National Hydrography Dataset (NHD) Web page http://nhd.usgs.gov/ (accessed January 2015). 
U.S. Geological Survey in cooperation with the U.S. Environmental Protection Agency, National Hydrography Dataset, 2015. Available at www.horizonsystems.com/nhdplus/

Van Sickle, J. and C.B. Johnson. 2008. Parametric distance weighting of landscape influence on streams. Landscape Ecology 23: 427-438.

Ver Hoef, J.M., E. Peterson, and D. Theobald. 2006. Spatial statistical models that use flow and stream distance. Environmental and Ecological Statistics 13(4): 449464.

Ver Hoef, J.M., E.E. Peterson, D. Clifford, R. Shah. 2014. SSN: An R Package for Spatial Statistical Modeling on Stream Networks. Journal of Statistical Software, 56(3), 1-43.

Verberk, W.C.E.P., I. Durance, I.P. Vaughan, and S.J. Ormerod. 2016. Field and laboratory studies reveal interacting effects of stream oxygenation and warming on aquatic ecotherms. Global Change Biology 22: 1769-1778.

Walsh, C.J., A.H. Roy, J.W. Feminella, P.D. Cottingham, P.M. Groffman, and R.P. Morgan II. 2005. The urban stream syndrome: current knowledge and the search for a cure. Journal of the North American Benthological Society 24(3): 706-723.

Wear, D.N., M.G. Turner, and R.J. Naiman. 1998. Land cover along an urban-rural gradient: implications for water quality. Freshwater Systems 8(3): 619-630.

Wente, S.P. 2000. Proximity-based measure of land use impacts to aquatic ecosystem integrity. Environmental Toxicology and Chemistry 19: 1148-1152. 
Yates, A.G. and R.C. Bailey. 2006. The stream and its altered valley: Integrating landscape ecology into environmental assessments of agro-ecosystems. Environmental Monitoring and Assessment 114(1-3): 257-271.

Zhou, T., J. Wu, and S. Peng. 2012. Assessing the effects of landscape pattern on river water quality at multiple scales: A case study of the Dongjiang River watershed, China. Ecological Indicators 23: 166-175. 
APPENDIX A

SPATIAL VARIATION IN MODEL RESIDUALS 
1. Spatial variation in residuals from dry seasonal models for Mean7dTmax.

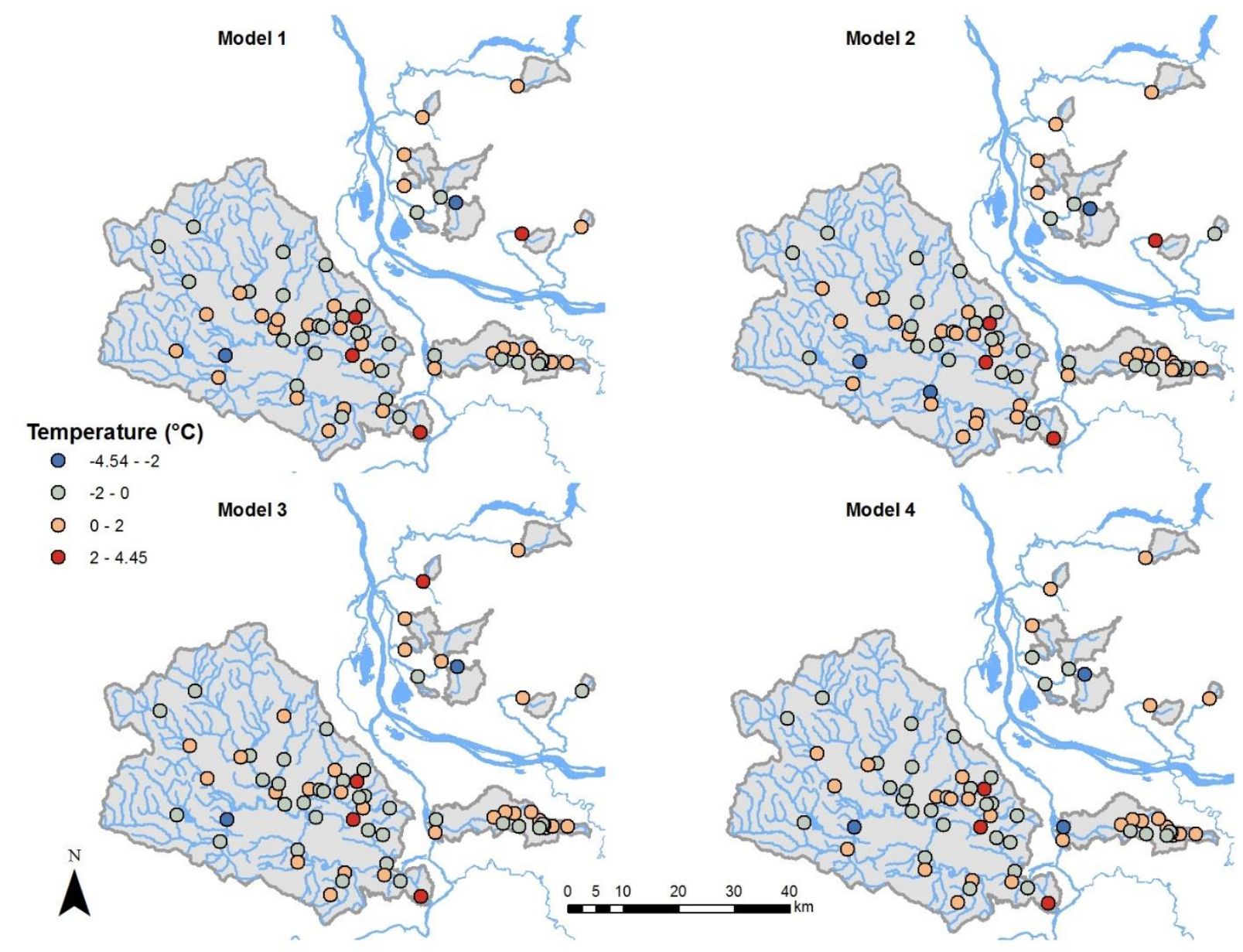


2. Spatial variation in residuals from dry season models for Range_DTR.

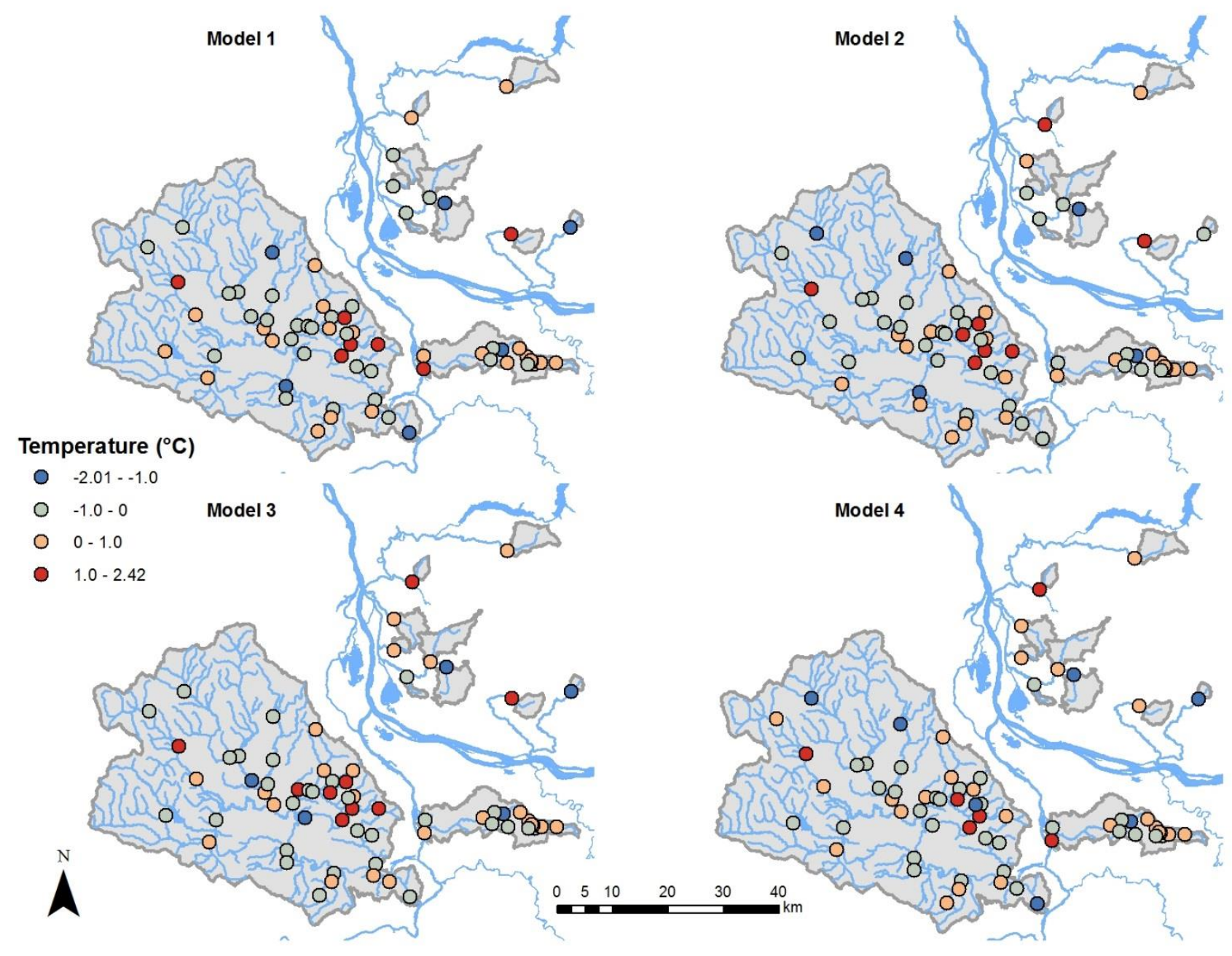


3. Spatial variation in residuals from dry season models for CV_Tmax.

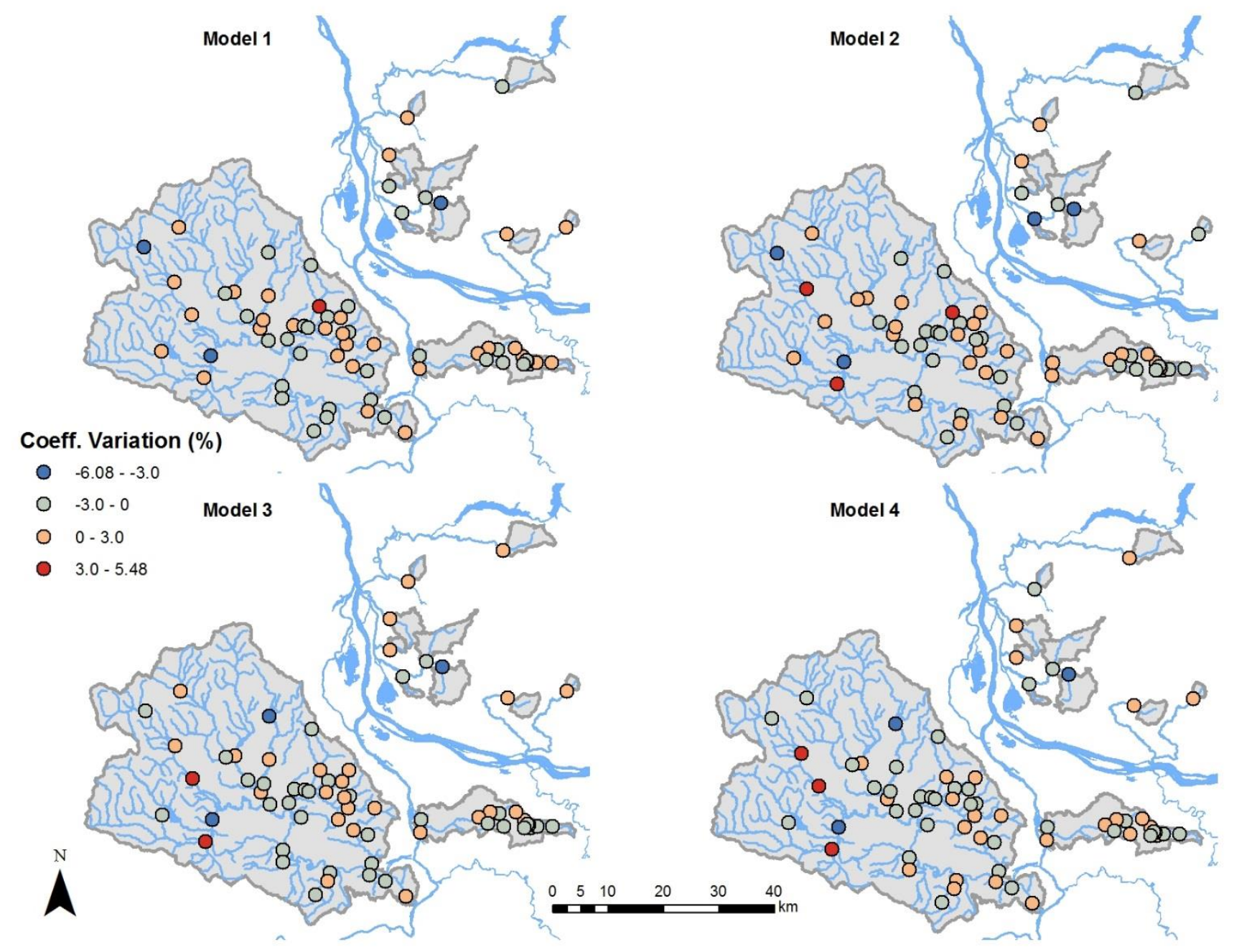


4. Spatial variation in residuals from models for $\operatorname{Tmax} 7 \mathrm{~d}>17.8$

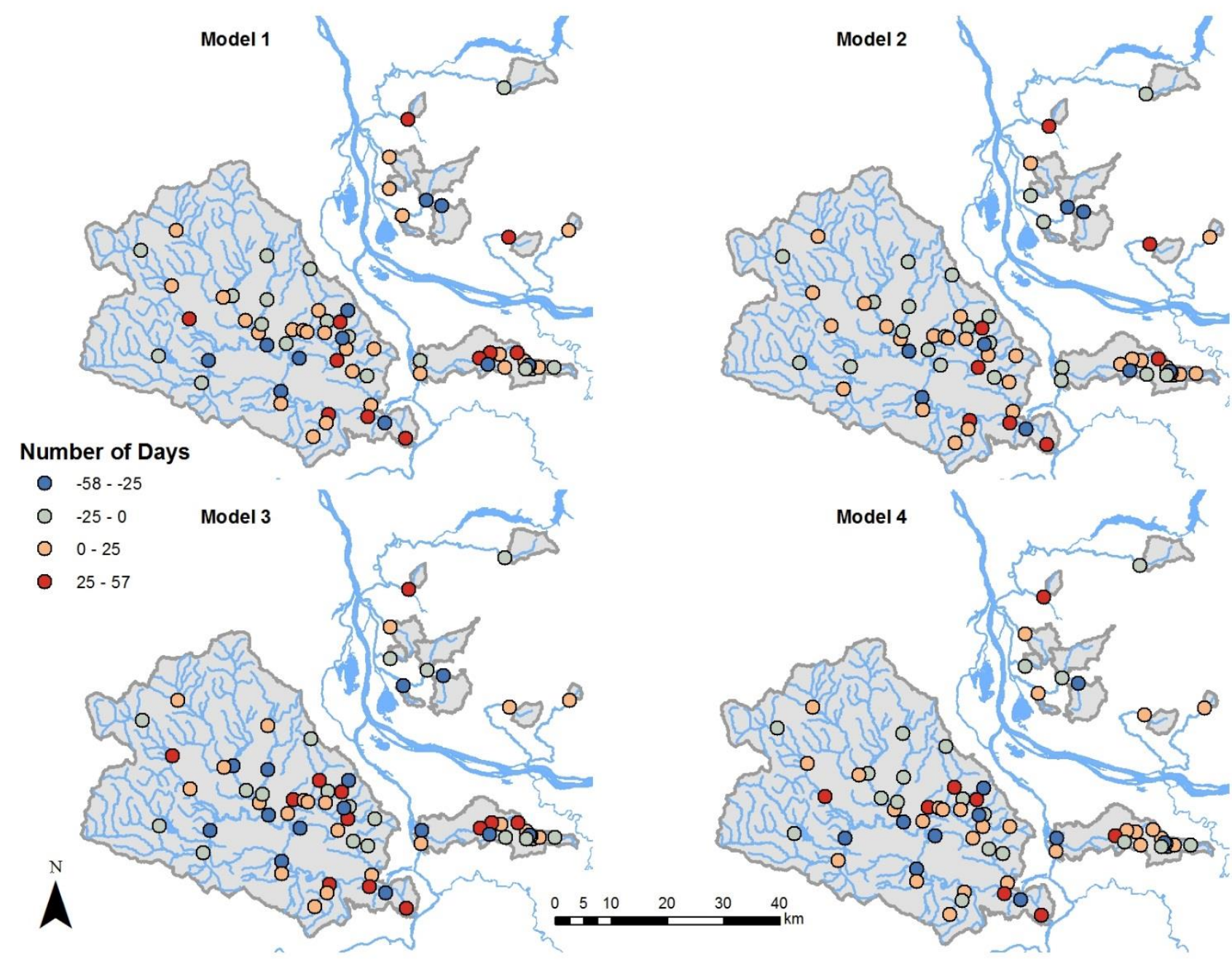


APPENDIX B

PYTHON SCRIPT FOR THE DISTANCE WEIGHTING TOOL 


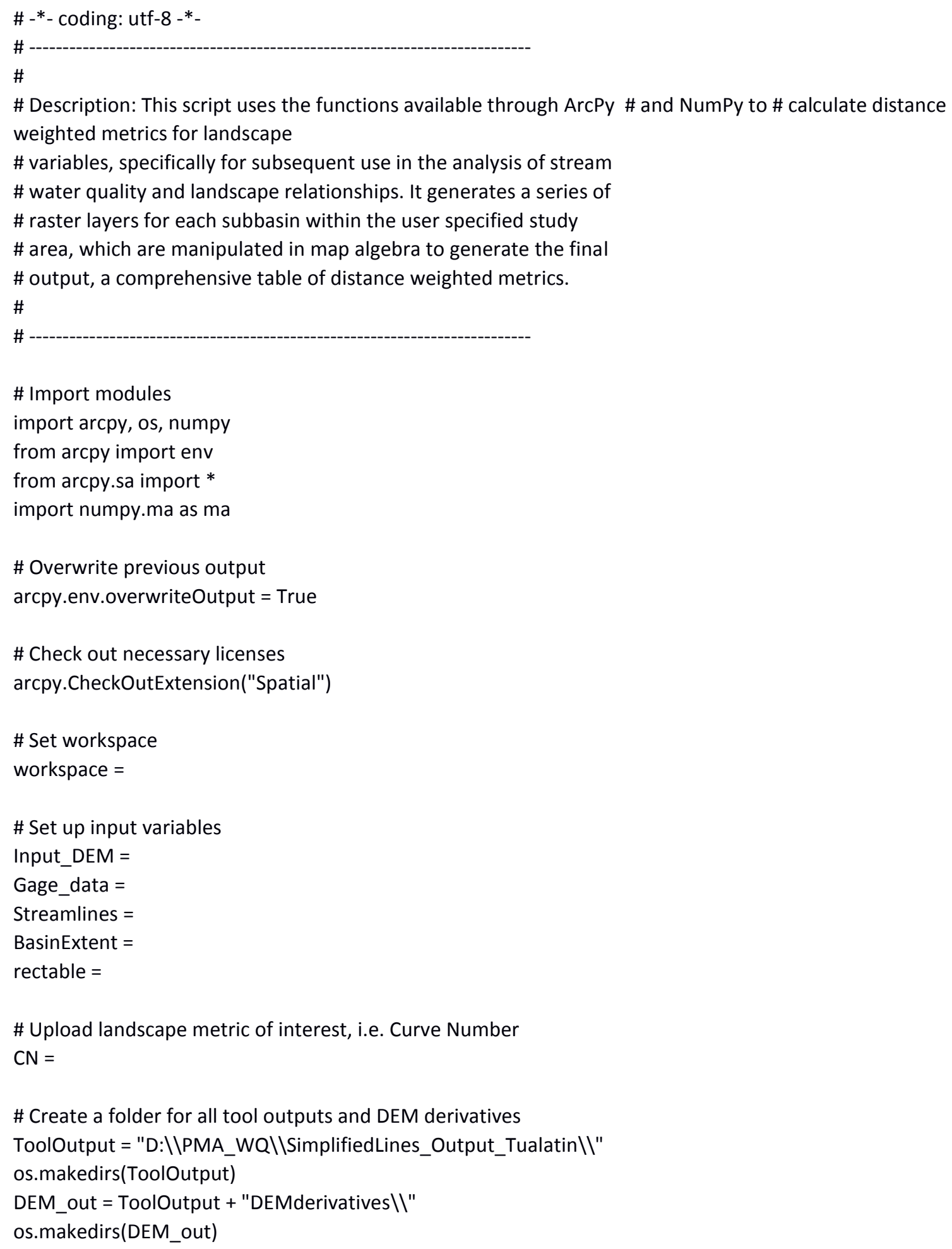




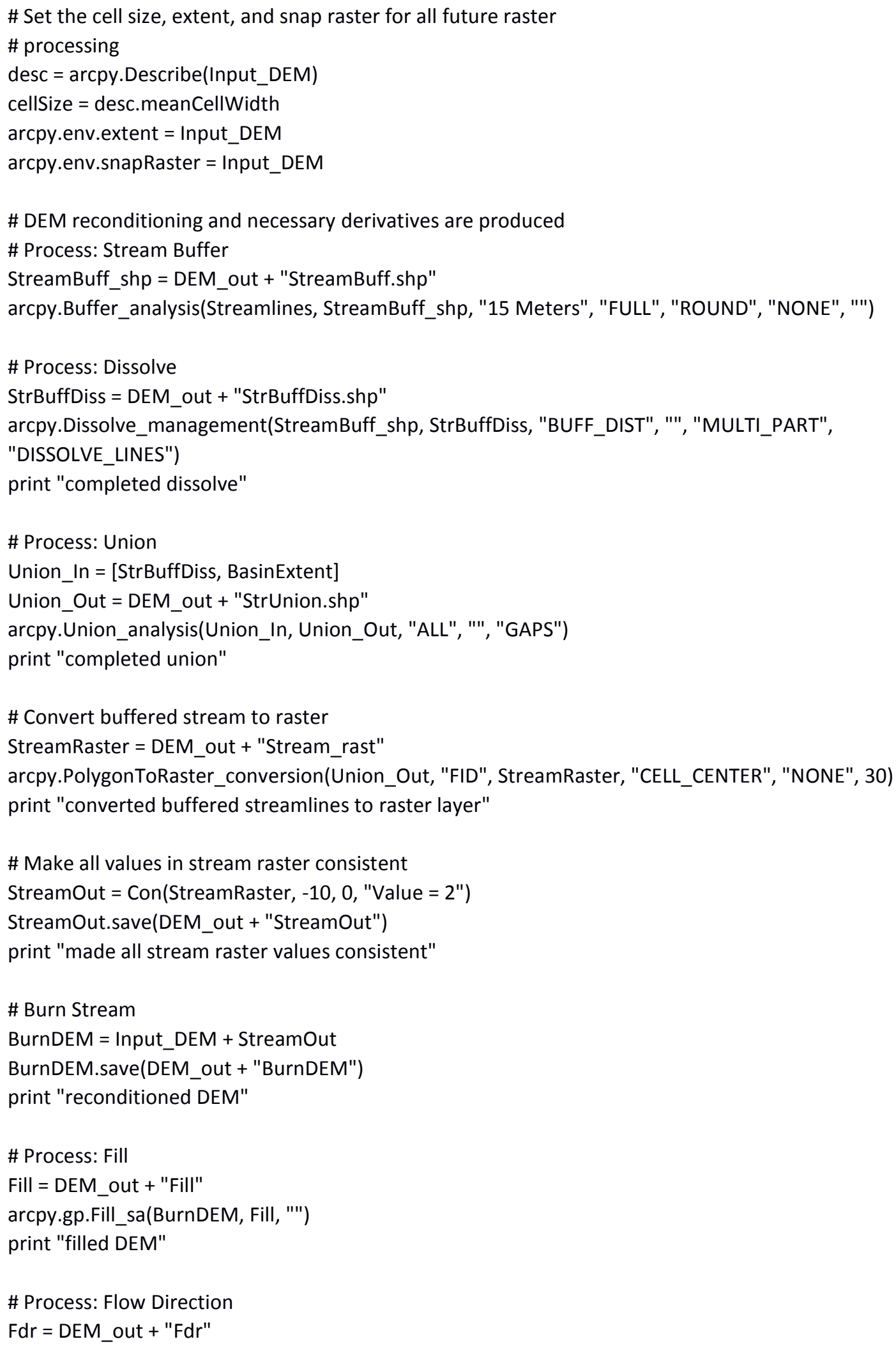




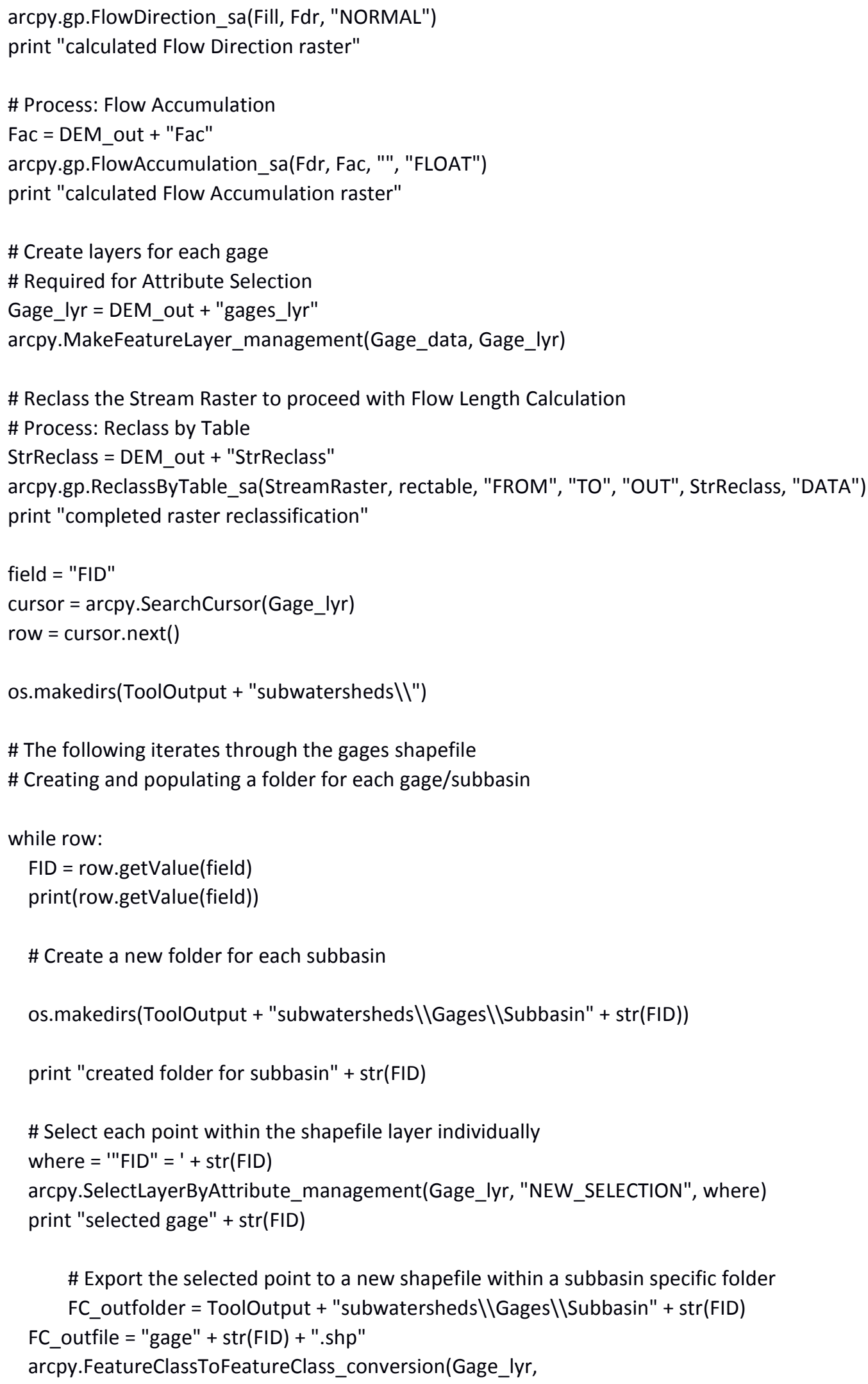


FC_outfolder, FC_outfile, where)

print "exported gage" + str(FID) + " to new shapefile"

\# Snap Pour Points, originally tried distance = "100"

InPoint = FC_outfolder + "II" + FC_outfile

SnapPoint = SnapPourPoint(InPoint, Fac, "300", "'")

SnapPoint.save(FC_outfolder + "IIsnap_pt" + str(FID))

print "snapped gage" + str(FID)

\# Watershed Delineation

Watershed_folder = ToolOutput + "subwatersheds $\backslash \backslash "$

Delineated_Watershed $=$ Watershed_folder + "subbasin" $+\operatorname{str}($ FID)

arcpy.gp.Watershed_sa(Fdr, SnapPoint, Delineated_Watershed, "VALUE")

print "delineated subbasin" + str(FID)

\# Convert to Polygon so that Rasters can be clipped

Watershed_shape $=$ Watershed_folder + "subbasin" + str(FID) + ".shp"

arcpy.RasterToPolygon_conversion(Delineated_Watershed, Watershed_shape, "NO_SIMPLIFY", "VALUE")

print "converted subbasin" + str(FID) + " extent to polygon"

row $=$ cursor.next ()

BurnDEM = DEM_out + "BurnDEM"

\# Redefine Workspace to get Watershed Rasters

arcpy.env. workspace $=$ ToolOutput + "subwatersheds \\"

\# Slope

Slope = Slope(Input_DEM, "DEGREE")

Slope.save(DEM_out + "Slope")

Slope = DEM_out + "Slope"

\# Create ultimate output file, needs to be in a local, non-networked

\# directory

\# When initially setting up the output file, also include a list of

\# variables to act has the header

landscape_metrics = open("pathname.txt", "w+")

landscape_metrics.write("gage_id, Size, Area_CN, IDW_CN, IDW_CN_OL, IDW2_CN, IDW2_CN_OL, PFAw_CN, 
AvgElev, IDW_Elev, IDW_Elev_OL, IDW2_Elev, IDW2_Elev_OL, PFAw_Elev, AvgSlope, IDW_Slope, IDW_Slope_OL, IDW2_Slope, IDW2_Slope_OL, PFAw_Slope, CN_Slope, IDW_CN_Slope, IDW_CN_Slope_OL, IDW2_CN_Slope, IDW2_CN_Slope_OL, PFAw_CN_Slope $(n ")$

\# Calculation of the Various Flow Lengths (Total, In-Stream, and

\# Overland)

subs $=$ arcpy. ListRasters ()

for sub in subs:

\# create a folder for flow lengths for the sub basin os.makedirs(ToolOutput + "FlowLengths \" + sub)

print "created Flow Length Folder for " + sub

FL_folder = ToolOutput + "FlowLengths $\backslash \backslash "+$ sub

\# Extract Flow Direction By Mask for the sub basin

SubFlowDir = FL_folder + "\\FlowDir"

arcpy.gp.ExtractByMask_sa(Fdr, sub, SubFlowDir)

print "clipped FlowDir for " + sub

\#\#\# Calculate Flow Lengths

\# Process: Total Flow Length

TotalFLOut = FL_folder + "\\FL_tot"

arcpy.gp.FlowLength_sa(SubFlowDir, TotalFLOut, "DOWNSTREAM", "')

print "calculated total flow length for " + sub

\# Process: Overland Flow Length

Overland_Out = FL_folder + "\\FL_overland"

arcpy.gp.FlowLength_sa(SubFlowDir, Overland_Out, "DOWNSTREAM", StrReclass)

print "calculated overland flow length for " + sub

\# Process: In-Stream Distance

InStream_Out = Raster(TotalFLOut) - Raster(Overland_Out)

InStream_Out.save(FL_folder + "\\FL_instream")

print "calculated in-stream flow length for " + sub

\# create a directory for landscape variables for the subbasin

os.makedirs(ToolOutput + "LandscapeVariables \\" + sub)

print "created Landscape Variable Folder for " + sub

\# create variable for that directory \#

Var_Folder = ToolOutput + "LandscapeVariables \\" + sub 


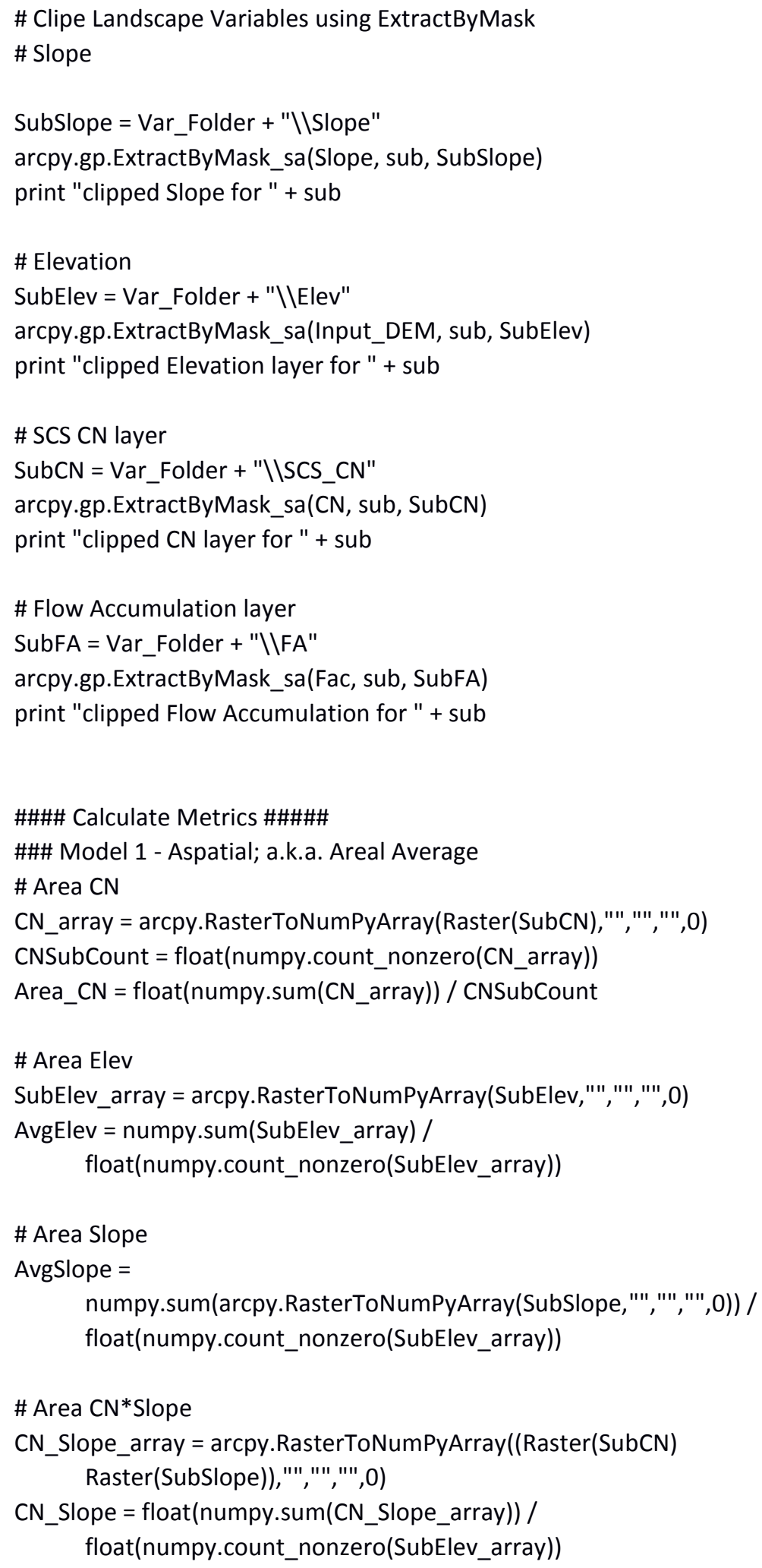




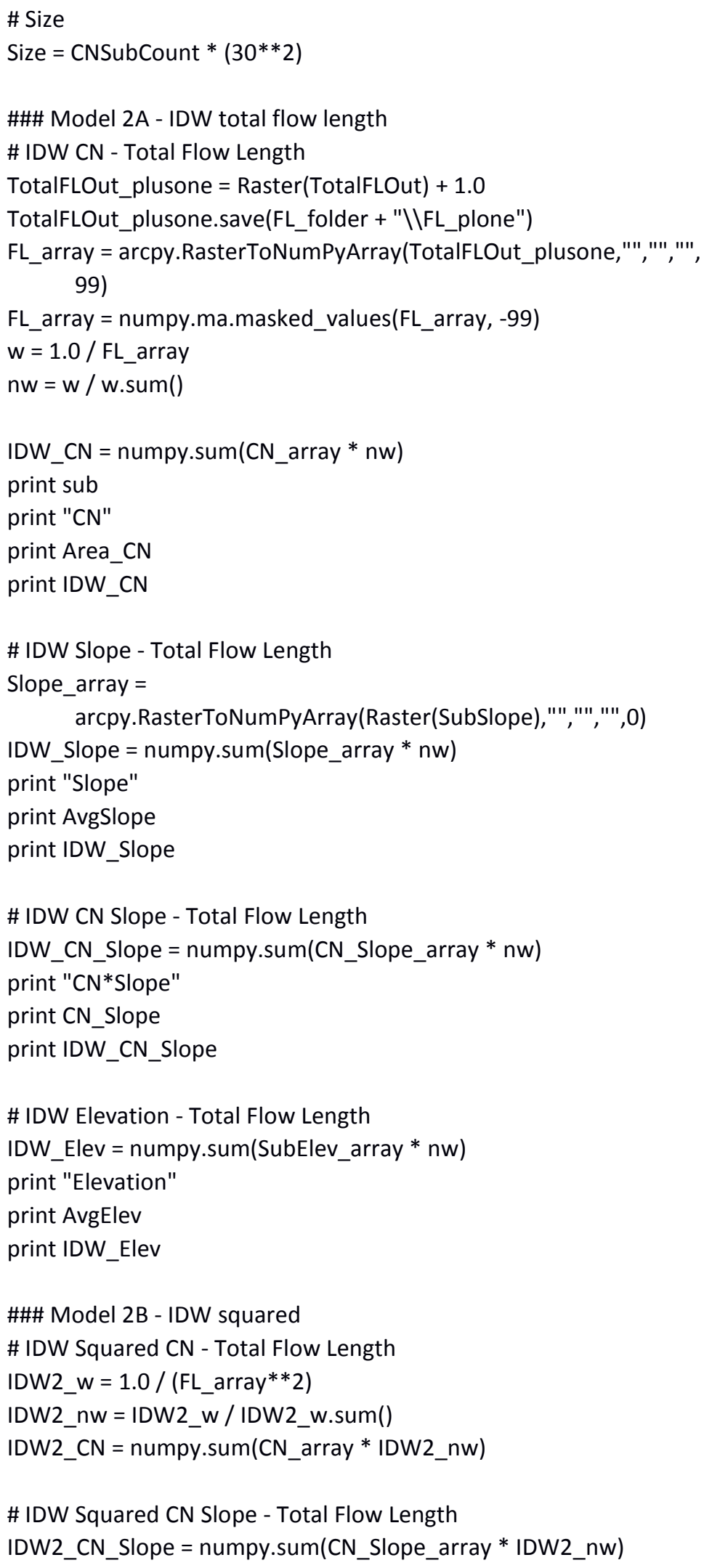




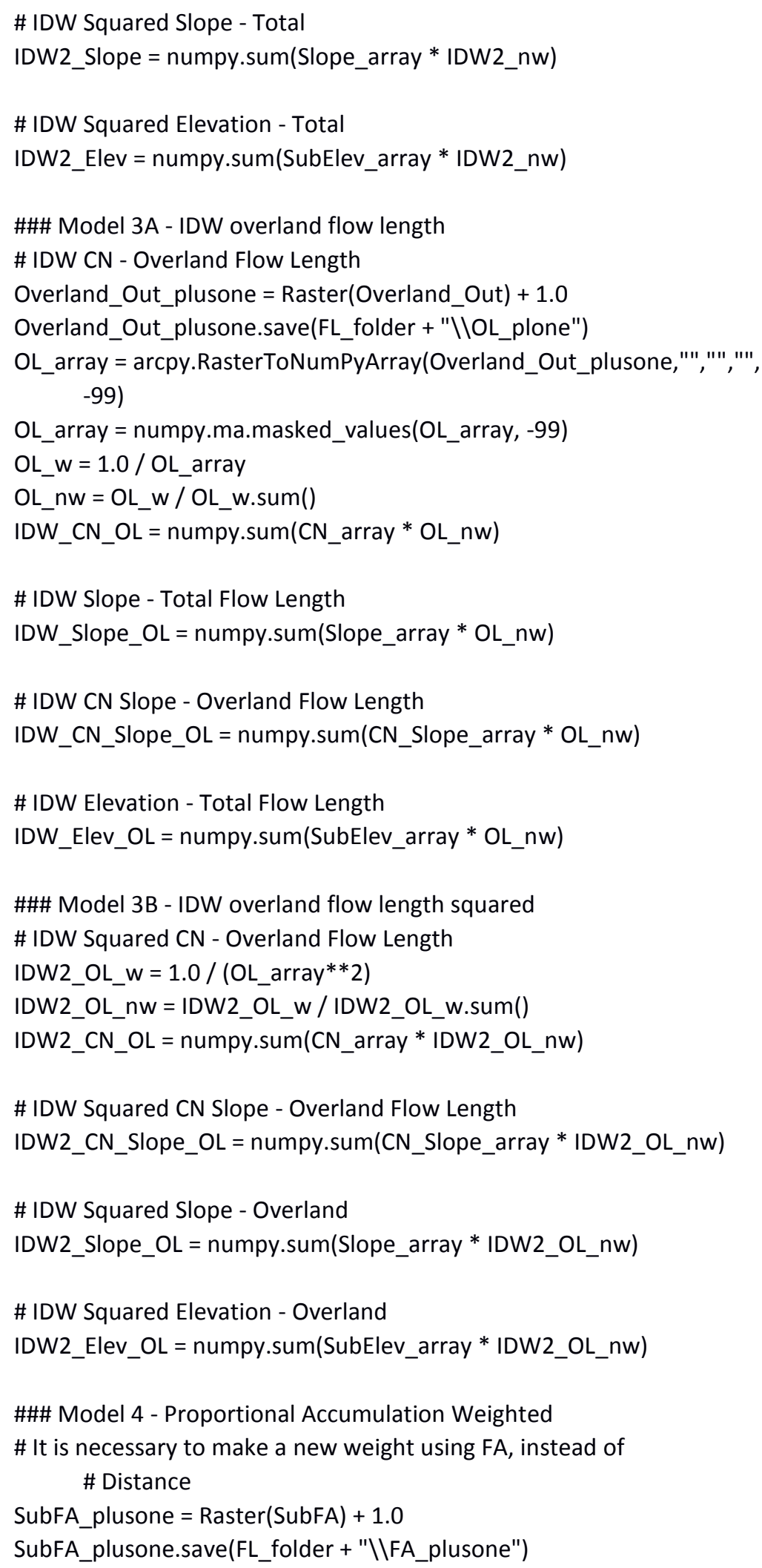




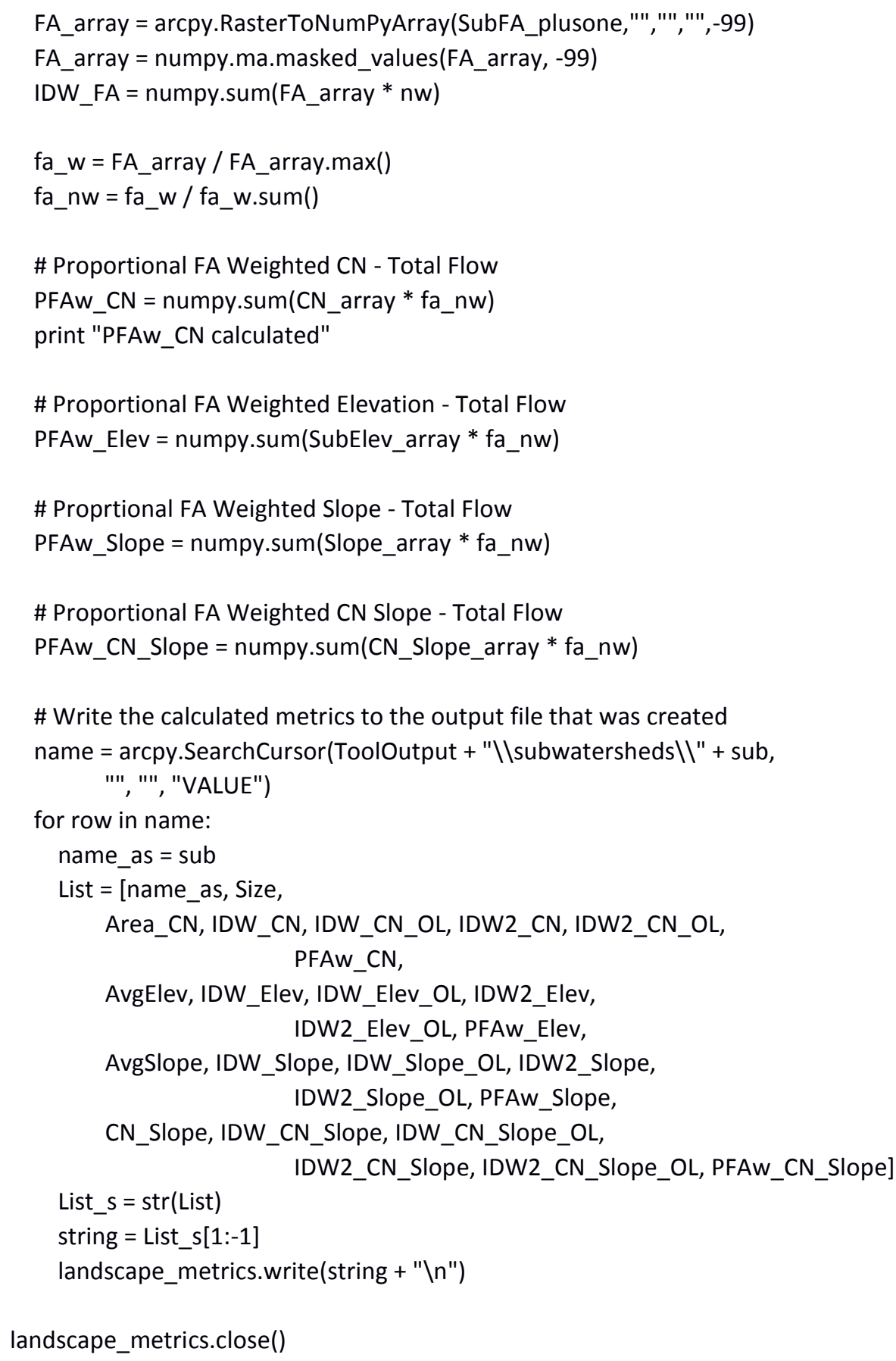

